\section{Designing a concept store: an interdisciplinary design process}

Silvia ROLLA ${ }^{1}$, ORCID: 0000-0002-3064-366X

Deniz HASIRCI ${ }^{2}$, ORCID: 0000-0001-9928-6077

Yücel Selin ANAL ${ }^{3}$, ORCID: 0000-0001-8611-4938

Zeynep EDES 4 , ORCID: 0000-0001-5802-701X

\begin{abstract}
The aim of this study is to introduce a design method for interior architecture education that would lead the students through the stages of the development of their projects. The design process is structured into five stages: concept development; spatial development; technical drawings and physical model; detailing and three-dimensional representation; finalization. The second goal is to adopt an interdisciplinary approach to stimulate creative thinking. Therefore, in this project interior architecture was related to several aspects of retailing and branding during the design process of a concept store. The proposed method has encouraged the formation of conceptual ideas in response to a defined design problem. By integrating interior architectural problems with retailing concepts, students have learned to analyze, research, devise design ideas, and transfer ideas into spatial compositions. This led to creative design solutions and diverse design approaches. The organization of the semester into stages has guided the students to approach the design problem gradually and to explore design solutions parallel to their conceptual ideas. By the end of the semester, the students were able to comprehend their progress along the design stages and to benefit from the interdisciplinary approach. Findings may be beneficial for students, design educators and designers interested in design process, interdisciplinarity processes, and designing retailing concept stores. The developed method may be used to provide students with structured design process skills.
\end{abstract}

\section{Highlights}

- The adoption of an interdisciplinary approach stimulates creative thinking.

- Dividing the design process into stages is helpful for students to approach the project correctly.

- Stages of design process support the systematic development of a design project.

- The interior architecture field may contribute greatly to the experience and value of brands.

- Interior architecture education can benefit from including knowledge regarding the profession's effects on brands.

\section{Keywords}

interior architecture education; interior design education; design studio; design process; interdisciplinary education

\section{Article Information}

Received:

03.03.2021

Received in Revised Form:

13.06.2021

Accepted:

07.07.2021

Available Online:

29.07 .2021

\section{Article Category}

Research Article

\section{Contact}

1. İzmir University of Economics, Faculty of Fine Arts and Design, İzmir, Turkey silvia.rolla@ieu.edu.tr

2. Izzmir University of Economics, Faculty of Fine Arts and Design, İzmir, Turkey deniz.hasirci@ieu.edu.tr

3. İzmir University of Economics, Faculty of Fine Arts and Design, İzmir, Turkey selin.anal@ieu.edu.tr

4. İzmir University of Economics, Faculty of Fine Arts and Design, İzmir, Turkey zeynep.edes@ieu.edu.tr 


\section{Bir konsept mağaza tasarlamak: disiplinler arası tasarım süreci}

Silvia ROLLA ${ }^{1}$, ORCID: 0000-0002-3064-366X

Deniz HASIRCI², ORCID: 0000-0001-9928-6077

Yücel Selin ANAL ${ }^{3}$, ORCID: 0000-0001-8611-4938

Zeynep EDES4 ${ }^{4}$ ORCID: 0000-0001-5802-701X

Öz

Bu çalışmanın amacı, içmimarlık eğitiminde kullanılmak üzere öğrencilere, aşama aşama ilerlemelerini sağlayacak olan bir yöntem sunmaktır. Tasarım süreci, beş aşama olarak kurgulanmıştır. İkinci amaç, süreçte yaratıcılı̆̆ı desteklemeye yardımcı olabilecek disiplinler arası bir yaklaşım izlemektir. Bu araştırmada içmimarlık, bir konsept mağazanın tasarımı sürecinde, perakende satış ve markalaşma ile ilişkilendirilmiştir. Önerilen yöntem, tanımlanmış tasarım problemine yanıt amaçlı kavramsal düşüncelerin gelişmesini teşvik etmiştir. Öğrenciler, içmimari problemleri, perakende satış kavramlarıyla ilişkilendirerek, analiz etmeyi, araştırmayı, tasarım fikri üretmeyi ve bunları mekansal kompozisyonlar haline getirmeyi öğrenmişlerdir. $\mathrm{Bu}$, yaratıcı tasarım çözümlerine ve farklı tasarım yaklaşımlarına ulaşmayı mümkün hale getirmiştir. Dönemin aşamalara ayrılmış olması, öğrencileri tasarım problemine kademeli olarak yaklaşmaya ve kavramsal fikirlerine paralel tasarım çözümleri bulmalarına yönlendirmiştir. Dönem sonunda, ögrenciler, aşamalardaki gelişmelerini kavrayabilmiş ve projenin disiplinler arası yaklaşımından yararlanmışlardır. Bulgular öğrenciler, tasarım eğitimcileri ve tasarım süreciyle, disiplinlerarasılık süreciyle ya da perakende satış mağazası tasarımıyla ilgilenen tasarımcılar için yararlı olabilir. Bu çalış̧mada geliştirilen yöntem, ögrencilere yapılandırılmış tasarım süreci becerileri sağlamak üzere içmimarlık eğitiminde kullanılabilir.

\section{Öne Çıkanlar}

- Disiplinler arası bir yaklaşımı benimsemek, yaratıcı düşünceyi tetikler.

- Tasarım sürecini aşamalara bölmek, öğrencilerin projeye doğru yaklaşımına yardımcı olur.

- Tasarım sürecinin aşamaları, tasarım projesinin sistemli bir şekilde gelişmesini destekler.

- İçmimarlık alanı, markaların deneyim ve değerine büyük katkıda bulunabilir.

- İçmimarlık eğitimi, mesleğin markalar üzerinde etkisine yönelik bilgiyi programa dahil etmekte yararlanabilir.

\section{Anahtar Kelimeler}

içmimarlık eğitimi; iç mekan tasarımı eğitimi; tasarım stüdyosu; tasarım süreci; disiplinler arası eğitim

\section{Makale Bilgileri}

Alind:

03.03.2021

Revizyon Kabul Tarihi:

13.06.2021

Kabul Edildi:

07.07.2021

Erişilebilir:

29.07.2021

\section{Makale Kategorisi}

Araştırma Makalesi

\section{İletişim}

1. İzmir Ekonomi Üniversitesi, Güzel Sanatlar ve Tasarım Fakültesi, İzmir, Türkiye silvia.rolla@ieu.edu.tr

2. İzmir Ekonomi Üniversitesi, Güzel Sanatlar ve Tasarım Fakültesi, İzmir, Türkiye deniz.hasirci@ieu.edu.tr

3. İzmir Ekonomi Üniversitesi, Güzel Sanatlar ve Tasarım Fakültesi, İzmir, Türkiye selin.anal@ieu.edu.tr

4. İzmir Ekonomi Üniversitesi, Güzel Sanatlar ve Tasarım Fakültesi, İzmir, Türkiye zeynep.edes@ieu.edu.tr 


\section{INTRODUCTION}

In this research, the study was conducted with sophomore students of Interior Architecture and Environmental Design department. The students were asked to design a new branch of a given existing concept store - a shop that sells a carefully curated selection of products connected to an overarching theme/idea - in Güzelbahçe, İzmir, Turkey. The main goal was to introduce a design method for interior architecture that would lead the students through the development of their project in one semester. An interdisciplinary approach was adopted to stimulate creative thinking. For this reason, interior architecture was linked to several aspects of retailing, such as brand identity, brand image, and brand experience. Store environments carry significance as the spatial reflection of brands, and interior architecture students need to be prepared for this growing demand. The integration of retailing aspects within the design process was necessary to develop an articulated research and incorporate the gained knowledge to define a concept and an articulated scenario that would lead the students to take decision in their project development.

Interior architecture is a dynamic field, both in terms of the ephemeral quality of interiors, but also concerning the changing materials, technology, and user demands. Interdisciplinarity appears to stand out as one of the most important contributors to the field. In design education, an interdisciplinary approach is based on a multidisciplinary vision of knowledge in which different disciplines are linked to each other to establish a dynamic interaction. However, interdisciplinarity differs from a multidisciplinary approach that more simplistically juxtaposes two or more disciplines. An interdisciplinary approach, instead, pursues a break of the disciplines' boundaries in order to understand and analyze the subjects from a complementary perspective (Darbellay, Moody \& Lubart, 2017). This study aims to join the fields of interior architecture and branding in one project. Much research has been done regarding interdisciplinarity in interior architecture education, as a means to increase creative and design thinking. Goodrich (2019) discussed the importance of the problem-solving component of education where graphic design students were involved in a community-based project where they were required to create brand identity. The students needed to do extensive research on cocoa cultivation - an area outside of their field contributing original input for the design process - in order to design for them. Klassen (2003) investigated creativity in the design studio, specifically with respect to small environments, with conceptual and practical aspects of design, where students' initiative was important. Clemons (2006) expressed that reflection was important for student learning and that they could help link 
theory to practice through the integration of different areas by a curious approach, research, leading to construction of meaning. Therefore, education in interior architecture needed to possess a similar quality to provide students for a challenging future. Research in the field provided important feedback; however, more updated and varied knowledge needed to be created. Mendoza et al. (2007) studied international opportunities education that enabled students to be involved in a more comprehensive approach linking design professions and had seen benefits such as, observing interrelationships between design fields as well as gain an appreciation of new perspectives and their own perspective within the design community. Hasirci and Demirkan (2007) dwelled on a creativity model to understand and enhance the interior design studio process. They discussed the significance of imagery within the design process and analyzed the stages of the interior design process (Demirkan \& Hasirci, 2009). Thamrin et al. (2019) focused on the importance of delivering social awareness in interior design education, human-centered design approaches in co-design, and collective creativity.

Design thinking as a terminology has been widely used in the design education field since the 1980s (Rowe, 1987) and today the adoption of design thinking is mentioned as a key distinguishing quality in several professions, aspiring to reach a point of certain value (Dorst, 2011; Panke, 2019).

Design thinking is connected to several disciplines, and thus borrows elements from all. (Renard, 2014). Thus, interdisciplinarity is in the fundamentals of this process. Moreover, the fact that design thinking has been widely accepted by both academia and practice of a variety of fields because it provides an original approach to problem solving (Micheli et al., 2018; Panke, 2019) putting users and interdisciplinarity to its core. In education, the process involves the students exploring and finding their style, designing their individual design processes, and collaborate as they work. The design process is not static and it needs to be experimented and recreated by investigating different approaches and continuously reflecting on the past process and product (Both, 2016).

The three-step understand, improve, apply design thinking process of The Stanford Design School (d.school) has since developed their model into a five-step one concerning these following stages; Empathize (seeking to understand the goals and users), define (creating the role objectives and major decisions), ideate (sharing ideas and both diverging and converging), prototype (making models, creating mockups, and iterating quickly), and test (finalization and understanding the impediments and identifying limitations) (Doorley et al., 2018), parallel to Cochrane and Munn's process model (2016), as well as the current study undertaking the stages, concept development, spatial development, technical drawings and model, detailing and three-dimensional representation, and finalization.

\section{INTERIOR ARCHITECTURE AND BRAND IDENTITY}

The final purpose of retail stores is to attract and retain customers (Babin \& Attaway, 2000). The design of store environments involves several factors that must be considered and analysed during the design process. From the interior architecture perspective, it involves design solutions of both interiors and exteriors under certain conditions determined by the stakeholder. The design must be carried out observing needs and requirements, but also envisioning possible variables that may 
occur in the future (Kent, 2000; Haug \& Münster, 2015). As a field, interior architecture has been gaining significance as brands realize the impact that spaces have on customer experience and behaviour, which in turn affect sales. Retail atmospherics enable environments to produce certain emotions in customers as well as employees (Kotler, 1973; Turley \& Milliman, 2000; Bitner, Booms \& Tetreault, 1990; De Ruyter \& Wetzels, 2000; Zomerdijk \& Voss, 2010) helping strengthen the brand identity. Although customers do not remember every part of their interaction with the brand space, they remember the sequence of events and especially the end (Hansen \& Danaher, 1999). This type of information has the potential to greatly contribute to the design of brand experiences.

Today, interiors are created to reflect rich messages associated with the brand, rather than act as a background (Frampton, 2005; Orth, Heinrich \& Malkewitz, 2012). Another feature is to create memorable experiences, necessitating an emotional relationship between the brand and the consumer (Ann, 2006; Srinivasan \& Srivastava, 2010). Rather than products and services alone, today consumers buy experiences (Schmitt, 1999). Interior design has a significant role in the differentiation between companies in attracting customers. Thus, contemporary approaches regarding interior design for brands is not a collection of the elements of the profession, such as layout, lighting, and colours, but their collective connotative meanings. The interior or atmosphere silently, but effectively brings the brand identity, products, and services together in one place (Kotler, 2000). Atmosphere involves the effects of spaces on customers using spatial design (Levy \& Kotler, 1979). Interior designers are expected to know and choose the consumers' preferences in e.g. colours, shapes, textures, before they even know themselves, and orchestrate them into complex categories (Veryzer, 1999). Holbrook (1999) states that in the era of experiential marketing, the importance of product performance has shifted to experiences.

The messages that are reflected by the brand involves services, products, and the environment, and the task of the interior designer is to successfully orchestrate these elements (Carbone \& Haeckel, 1994). Carbone and Haeckel (1994) call these 'clues', to which humanics could be added involving aspects related to people, such as behaviour of both consumers and employees influencing perceived quality and customer satisfaction (Bitner, Booms \& Tetreault, 1990; De Ruyter \& Wetzels, 2000). The cues or clues produce the context or atmosphere in which an experience is created. Thus, retail environments can create powerful emotional effects, which is noticed more and more each day (Zomerdijk \& Voss, 2010).

Combining the design of both exteriors and interiors has become a key aspect of the spatial experience of the brand (Conran, 1996). Within this need, 'inside-out' store design, creation of 'hybrid stores' and 'third-spaces' that combine a variety of uses and functions related to the brand have become significant in focusing on interior sales space (Kent \& Stone, 2007).

\section{Senses in Brand Experience}

All senses are active in brand experience, forming its identity and value systems. Sight alone involves colour, light, contrast, graphic design, and all spatial aspects of the experience (Hultén, 2011).

Brand image has been defined as a series of perceptions about a brand the consumer formulates as reflected by brand associations (Keller \& Lehmann, 2006) or symbolic meanings consumers 
remember when they interact with features of the product or service (Padgett \& Allen, 1997). Brand image refers to the collection of beliefs, experiences, perceptions, and values that consumers associate with the brand (Baloglu \& Brinberg, 1997; Ryu, Lee \& Kim, 2012). Thus, consistent positive experiences over time lead to positive image, and vice versa (Ostrowski, O’Brien \& Gordon, 1993), and service quality depends directly on the image. As the media that enables physical contact, interior architecture has a large role in shaping the brand image (Ryu, Lee \& Kim, 2012). Smith and Colgate (2007) have stated that the physical environment of the brand can provide functional/instrumental value, experiential/hedonic value, symbolic/expressive value, and cost/sacrifice value, and that these vary from brand to brand.

Relating brand image and experience to the education of the field has gained significant prevalence and continues to do so with increasing competition and demand from the market. The more knowledge is created regarding brands and the power of interior architecture, the need to bring it into higher education becomes more evident.

\section{Concept Stores in Retailing Context}

A concept store is a particular type of retail store that provides a collection of objects accurately selected according to an overarching idea to provide unique value in the market. Designed to represent a specific customer segment, the merchandise is presented to tell a story and to embody the lifestyle of the customer. Strategic positioning is essential to gain a thorough understanding of the profile of the customer, to define the product selection, and to communicate the idea of the store (Kumar, 2019; Popescu \& Popa, 2012; Wortzel, 1987).

The selection of the products may vary according to the concept and it may cover categories of items such as clothing, accessories, house decoration and textiles, objects of everyday use, technology, books, food, etc. (Popescu \& Popa, 2012). Usually, concept stores renovate their selection periodically, for longer or shorter periods, but in a regular manner. However, even though the merchandise exhibited is often temporary, the target group of customers remains constant and encouraged to return to the store periodically (Dubuisson-Quellier, 2007; Kumar, 2019; Pavel, 2016; Popescu \& Popa, 2012).

Nowadays, retailing has become very ambitious and retailers have understood that new launches and lower prices are not sufficient factors for competitive marketing. Thus, offering pleasant and engaging experiences in retailing environments turned out to be relevant for the customers (Grewal, Levy \& Kumar, 2009; Morganosky \& Cude, 2000, Otnes, Ilhan \& Kulkarni, 2012; Puccinelli et al., 2009; Srivastava \& Kaul, 2014; Verhoef et al., 2009). Concept stores provide a comprehensive shopping experience for their customers. They may often combine retailing with other activities, such as restaurants, bars, art galleries, bookstores, workshop areas, and specialized corners in the store itself. The idea of the concept store is to combine commerce with entertaining and cultural formulas, to highlight the singularity of the selected products and associate them with the profile of the customers. In this way, purchasing becomes more 'leisure and pleasure', than 'shopping for purpose' (Pavel, 2016, p. 172). Design, fashion, music, and arts are combined with shopping into a single experience, offering to the customer entertainment, fun, inspiration, sense of community, and surprise in a multi-sensory and innovative way (Kelly, 2002; Kumar, 2019; 
Schmitt \& Simonsen, 1997). Thus, experience becomes a differentiating element. Flexibility allows stores to transform and accommodate diverse commercial and social needs (Peñaloza, 1999).

Interior architecture has assumed greater significance as experience has become a key element for store environments (Kent, 2007). Interior architecture is crucial to deliver the concept of the store and the brand, to induce a comprehensive engagement with the customer, and to create shopping value. Thus, determinant for the spatial organization of the shop is the customer (DubuissonQuellier, 2007).

New engaging strategies that relate to emotions and senses are brought together with spectacle and theatre to arise awe and expectancy (Beverland \& Morrison, 2003). The selection of the design elements, such as materials, layout, colours, have to be genuinely combined according to the overarching theme of the store and the intended atmosphere (Bardsley, 2017). As the digital and physical dimensions often collide, intelligent product display, interactivity, and digital technology are used to create a personally tailored shopping experience (Bardsley, 2017).

Concept stores gather an ample spectrum of retailing design aspects. Great attention is put in the holistic representation of the store concept and the inclusive experience of the consumer in the shop. For this reason, interior architects have to consider and analyse many aspects to design successful and engaging retailing spaces.

\section{THE CONCEPT STORE PROJECT}

\section{Brief}

The project was developed by the students of the design studio of the second-year spring semester, department of Interior Architecture and Environmental Design, İzmir University of Economics. It was conducted during the academic year 2018-2019. The course took place two days a week for 14 weeks. The classes were taught in 4 -hour block periods. The first hour was usually earmarked for theoretical lectures, during which one of the instructors or an external guest taught the specific subject of the week. Alternatively, a general discussion of the projects was carried out in the class. The following three hours were reserved for one-on-one critique sessions. There were 43 students in the studio and six instructors. Groups of seven or eight students were assigned to one instructor for individual critiques, rotating each week to ensure maximum variation and proliferation of ideas.

The main goal of the studio was to stimulate creative ideas for the development of an interior architecture project adopting an interdisciplinary approach. As interior architecture was linked to retailing, the students were asked to design the branch of a given existing concept store among a given list. Students developed detailed research on the particular brand they choose. Undertaking research on different disciplines gave the students a higher level of knowledge and understanding as well as grounding and contextualizing their ideas. Students developed better problem solving skills because they were able to structure their more creative and intuitive decisions. The process gave students a broader view and helped them to come up with better solutions to problems. Students had to research on target groups, brand's aim, merchandise, and price range. This was 
helpful for them to understand brands and concept store dynamics. Therefore, they were asked to interpret and reflect the identity of the brand for a new branch of the same concept store.

The spatial program consisted of an entry, display areas, changing rooms, along with spaces for design, office work, and storage. Other specialized areas were added according to each concept and scenario.

The building is located along the coast of Güzelbahçe, İzmir. Güzelbahçe is a suburb between Izmir and Urla. The site is on the outlet of the narrow gulf of İzmir Bay and faces the north wind from the sea. The urban fabric is not dense, and the buildings are about two to four floors high. Until 1980s, it was as a summer town but now, since the transportation amenities have improved, people accommodate in Güzelbahçe during both summer and winter. In immediate proximity of the project site, there are restaurants and residential buildings. The place is mostly populated by families who work in downtown İzmir. On the weekends, Güzelbahçe is very crowded with people visiting from the city. The traffic is heavy especially during summer months (Figure 1).
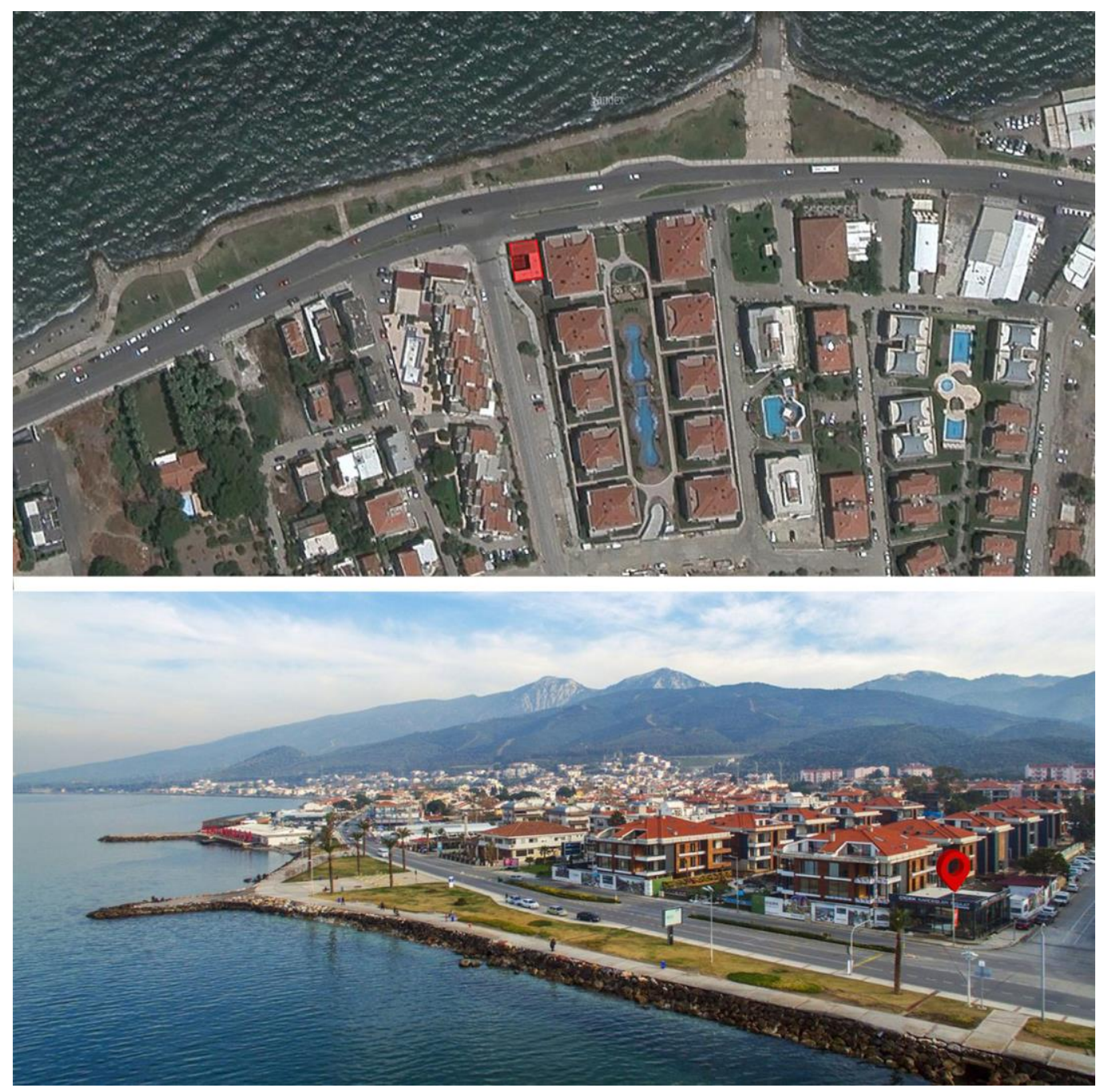

Figure 1 - Project site [Above: Satellite view; Below: Aerial view]

(Photo credits: Çiçek Kardeşler İnşaat Ltd. Şti.) 


\section{Stages of the Design Process}

The academic semester was divided into five stages: concept development (stage I), spatial development (stage II), technical drawings and model (stage III), detailing and three-dimensional representation (stage IV), and finalization (stage V). A jury was held at the end of each stage so that each student could get feedback for their design (Table 1).

Table 1 - Stages of the Design Process

\begin{tabular}{|c|c|c|c|}
\hline $\begin{array}{c}\text { Stages of the } \\
\text { design process }\end{array}$ & General criteria & Outputs & Evaluation \\
\hline $\begin{array}{l}\text { Stage I: } \\
\text { Concept } \\
\text { development }\end{array}$ & $\begin{array}{l}\text { - Brand research } \\
\text { - User groups identification } \\
\text { - Site analysis } \\
\text { - Main concept statement and } \\
\text { mood board } \\
\text { - Product selection } \\
\text { - Creation of a scenario }\end{array}$ & $\begin{array}{l}\text { - A1 poster with research on the } \\
\text { brand identity and the users } \\
\text { group } \\
\text { - A1 poster with concept } \\
\text { statement and scenario for the } \\
\text { project }\end{array}$ & $\begin{array}{l}\text { - Quality of in-depth research } \\
\text { - Consistency of concept and } \\
\text { scenario with analysis } \\
\text { - Feasibility of the concept } \\
\text { - Relevancy of scenario and user } \\
\text { profile }\end{array}$ \\
\hline \multicolumn{4}{|c|}{ Pre-jury I } \\
\hline $\begin{array}{l}\text { Stage II: } \\
\text { Spatial } \\
\text { development }\end{array}$ & $\begin{array}{l}\text { - Spatial and functional layout } \\
\text { according to site analysis, } \\
\text { scenario, and concept } \\
\text { - Circulation } \\
\text { - Private/public relationship. } \\
\text { - Interior/exterior relationship }\end{array}$ & $\begin{array}{l}\text { - Bubble diagrams } \\
\text { - Schematic plans and sections } \\
\text { - Revision of the previous stage }\end{array}$ & $\begin{array}{l}\text { - Coherence of the space layout } \\
\text { and stage I outputs } \\
\text { - Feasibility of functions and } \\
\text { circulation. }\end{array}$ \\
\hline \multicolumn{4}{|c|}{ Pre-jury II } \\
\hline $\begin{array}{l}\text { Stage III: } \\
\text { Technical } \\
\text { drawings and } \\
\text { model }\end{array}$ & $\begin{array}{l}\text { - Study of volumes } \\
\text { - Development of schematical } \\
\text { plans and section into a } \\
\text { consistent design solution }\end{array}$ & $\begin{array}{l}\text { - 1:50 scale plans and sections } \\
\text { with interior layout, furniture } \\
\text { decisions, structural system } \\
\text { - 1:50 scale model } \\
\text { - Revision of the previous stages }\end{array}$ & $\begin{array}{l}\text { - Originality and feasibility of } \\
\text { the design solution } \\
\text { - Accuracy of the technical } \\
\text { drawings } \\
\text { - Use of architectural } \\
\text { conventions }\end{array}$ \\
\hline \multicolumn{4}{|c|}{ Pre-jury III } \\
\hline $\begin{array}{l}\text { Stage IV: } \\
\text { Detail and 3d } \\
\text { representation }\end{array}$ & $\begin{array}{l}\text { - Research on detailing and } \\
\text { production process } \\
\text { - Elaboration of design ideas } \\
\text { into construction drawings } \\
\text { - Selection of materials, colours, } \\
\text { and textures } \\
\text { - Realization of a digital 3D } \\
\text { model and representation of the } \\
\text { three-dimensional space }\end{array}$ & $\begin{array}{l}\text { - } 1: 20 \text { or smaller detail drawings } \\
\text { of significant portions of project } \\
\text { - 3D views of the project } \\
\text { - Revision of the previous stages }\end{array}$ & $\begin{array}{l}\text { - Coherence of the details and } \\
\text { the general design idea } \\
\text { - Feasibility of the design } \\
\text { solution } \\
\text { - Ability to represent a three- } \\
\text { dimensional space into a } \\
\text { perspective view }\end{array}$ \\
\hline \multicolumn{4}{|c|}{ Pre-jury IV } \\
\hline $\begin{array}{l}\text { Stage V: } \\
\text { Finalization }\end{array}$ & $\begin{array}{l}\text { - Improvement and eventual } \\
\text { revision of the previous stages } \\
\text { - Finalization of the design idea } \\
\text { and the solution } \\
\text { - Design of the final } \\
\text { presentation boards }\end{array}$ & $\begin{array}{l}\text { - A0 board with the study of the } \\
\text { selected brand, concept, and } \\
\text { scenario. } \\
\text { - A0 board with 1:50 scale plans } \\
\text { and section, 3D views } \\
\text { - 1:50 scale model } \\
\text { - Additional board(s) with } \\
\text { material selections and detailing } \\
\text { - Revision of the previous stages }\end{array}$ & $\begin{array}{l}\text { - Coherence of the design } \\
\text { process } \\
\text { - Overall project development } \\
\text { within each stage } \\
\text { - Ability to present design ideas } \\
\text { and solutions. }\end{array}$ \\
\hline \multicolumn{4}{|c|}{ Final jury } \\
\hline
\end{tabular}


At the concept development stage (stage I), students devised a theme that was derived from their research. They researched the brand, brand identity, product selection, price range, project site, history, user groups, and anything that they found relevant. At this stage, they also pre-pared a mood board, which is a collage of text and images that expresses the feeling of the space to be designed.

The spatial development stage (stage II) is the part of the process in which floor plans and sections are formed out of bubble diagrams. Bubble diagrams were used to analyse the relation-ships among functions and circulation. During this stage, schematic plans and sections were created accordingly. These schemes turned into more developed drawings that reflected the initial design decisions.

The drawings were elaborated into more detailed floor plans and sections as technical drawings (stage III). Design elements, such as layout, volumes, colours, and lighting, were defined. The project was developed at 1:50 scale to represent interior arrangements and furniture selections, and materials specifications. The model was essential for the students to understand the vol-umes and the overall composition.

Finally, at the stage IV, students were asked to further develop their project with construction drawings. A careful selection of detail drawings was produced for chosen areas at 1:20 scale or smaller. The selected detail had to be significant for the overall project. In this way, the ideas that form the space were not abandoned at the production stage.

As the final stage (stage V), the project and drawings were finalized. The entire design process was brought together to be consistent at each level. The students were asked to compose two presentation boards to present their projects. Furthermore, students submitted a model in 1:50 scale, a material board, and a folder that contained technical details and all the previous works, from the first analysis until the very last submission in chronological order.

\section{RESULTS}

Five projects were selected for this study. The selection was made according to the consistency of each stage and the ability to address creative design solutions based on the satisfaction of the requirements for each stage. Projects are presented by stages of the design process.

\section{Stage I: Concept Development}

In the first stage, the initial research on the brand identity was developed to ideate a conceptual idea that would lead the students through the design of their project. The study was supported with inspirational sources and images selected by the students. Parallel to this, the project site was analysed to grasp the characteristics of the building, the surroundings, and the neighbour-hood. The students were to define the scenario together with the formation of the user profile. 


\section{Project I}

In this project, the target group of the brand included people that were actively involved in building a community with particular attention for sustainability, with strong appreciation of art, music, and food. In this store, customers can socialize, improve their skills with workshops, and find specific products within a natural atmosphere. The idea was to bring together different spaces into an open system. Furthermore, as the store is located in a suburban area, the concept store would become a transition point between the city and natural destinations (Figure 2).

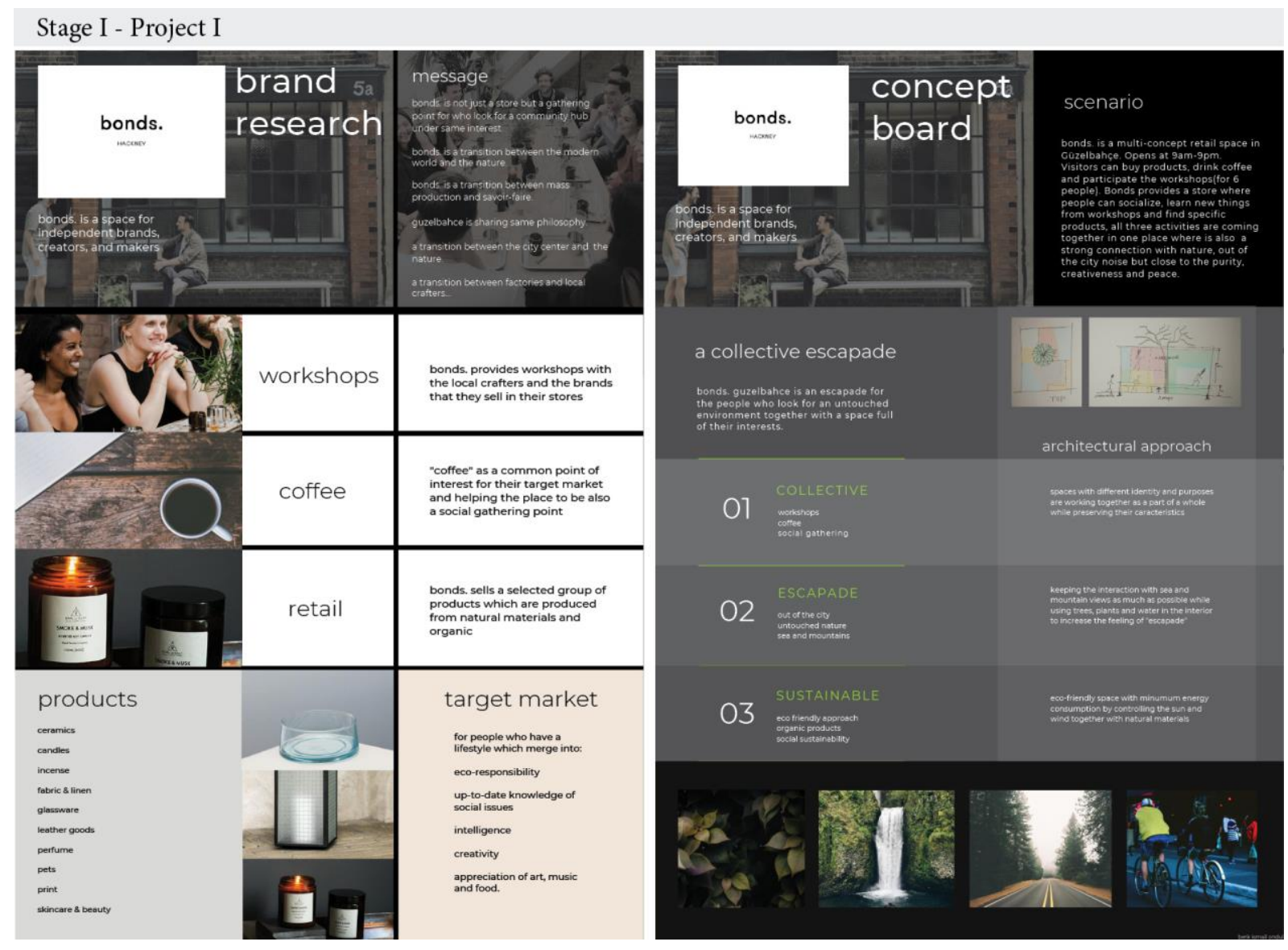

Figure 2 - Stage I - Project I 


\section{Project II}

In the second project, the aim was to gather both local and international creatives in order to reframe the global institutions of the new century. Cultural events, music, and exhibitions were offered along with retailing. The concept was to create a space-time experience in an intercul-tural environment. The store offers a promenade where different cultures are displayed and where innovation is encouraged (Figure 3).

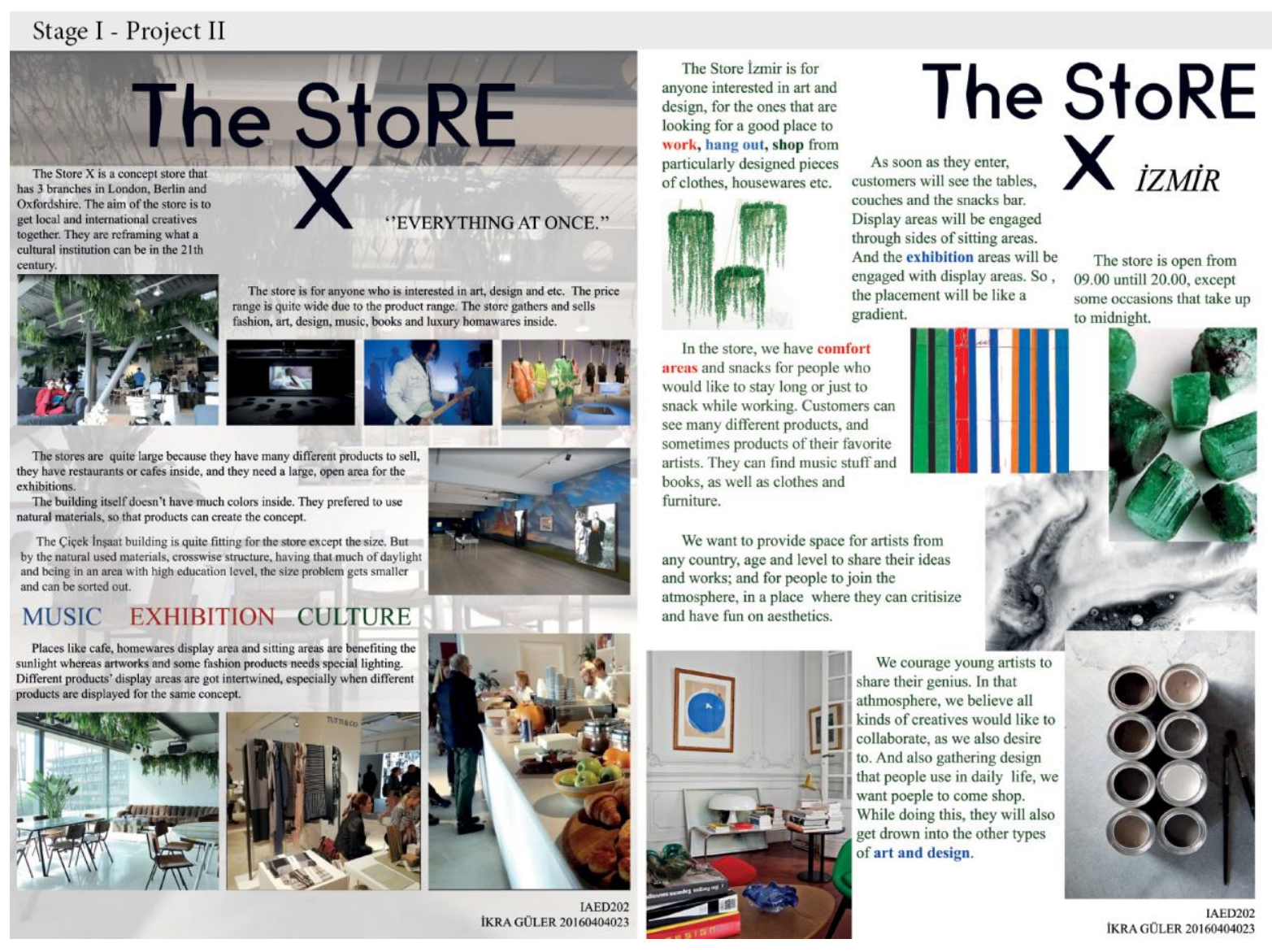

Figure 3 - Stage I - Project II 


\section{Project III}

The concept was to assemble communities that work in creative industries and to break the boundaries of traditional art and fashion. The target group included customers open to innovation, multiculturalism, and seeking products of last generation. By the means of innovation, the visitors would be guided into the ultimate retail experience. A wide range of products was of-fered along with cultural events and performances (Figure 4).

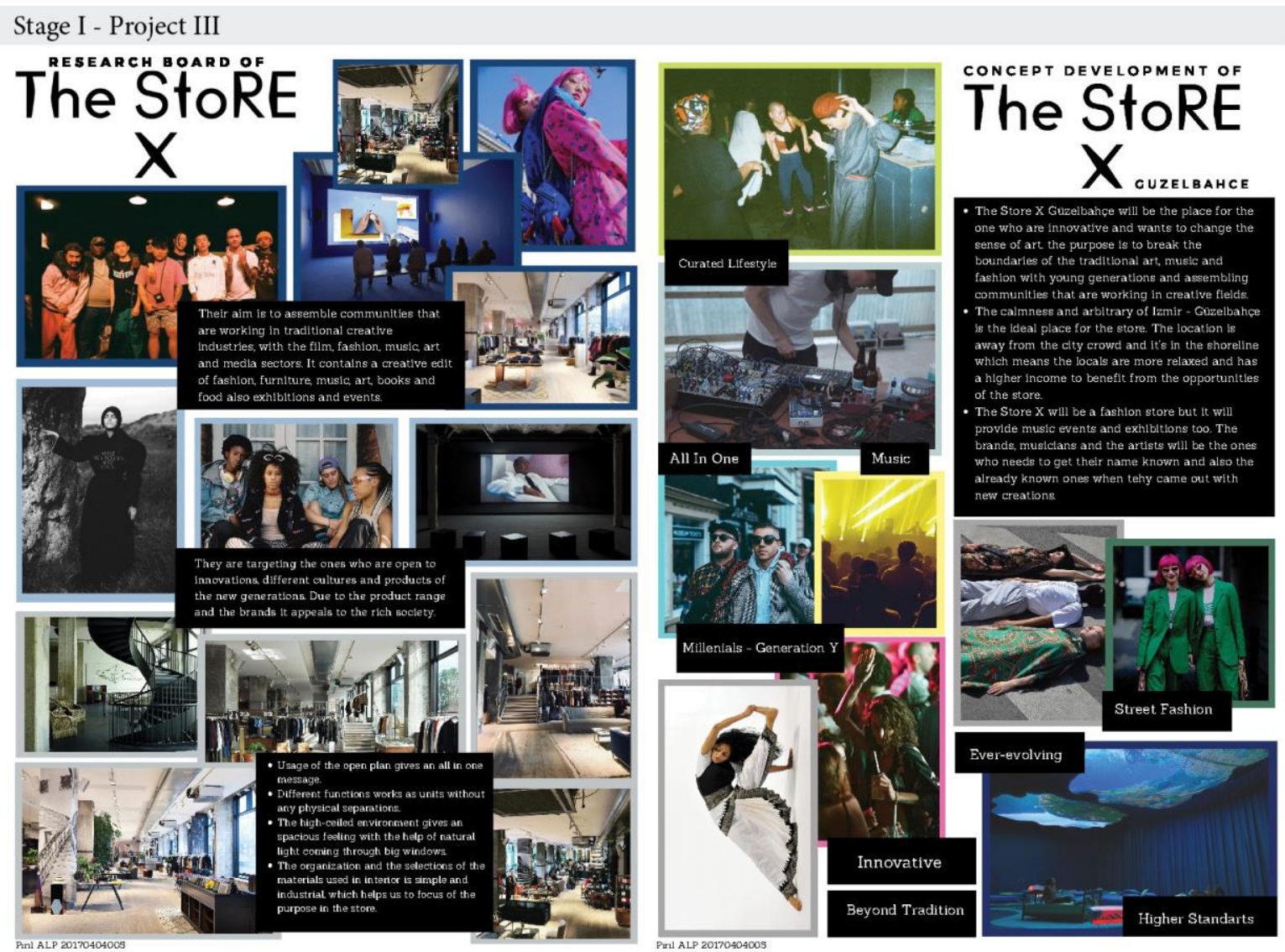

Figure 4 - Stage I - Project III 


\section{Project IV}

The fourth project turned around the idea of reinterpreting an iconic car with a futuristic read-ing. Elements from past, present, and future would be blended in an atmosphere in which brand and design values become protagonists. Visitors would be able to get to know the exhibited car prototype with technological and architectural solutions (Figure 5).

Stage I - Project IV
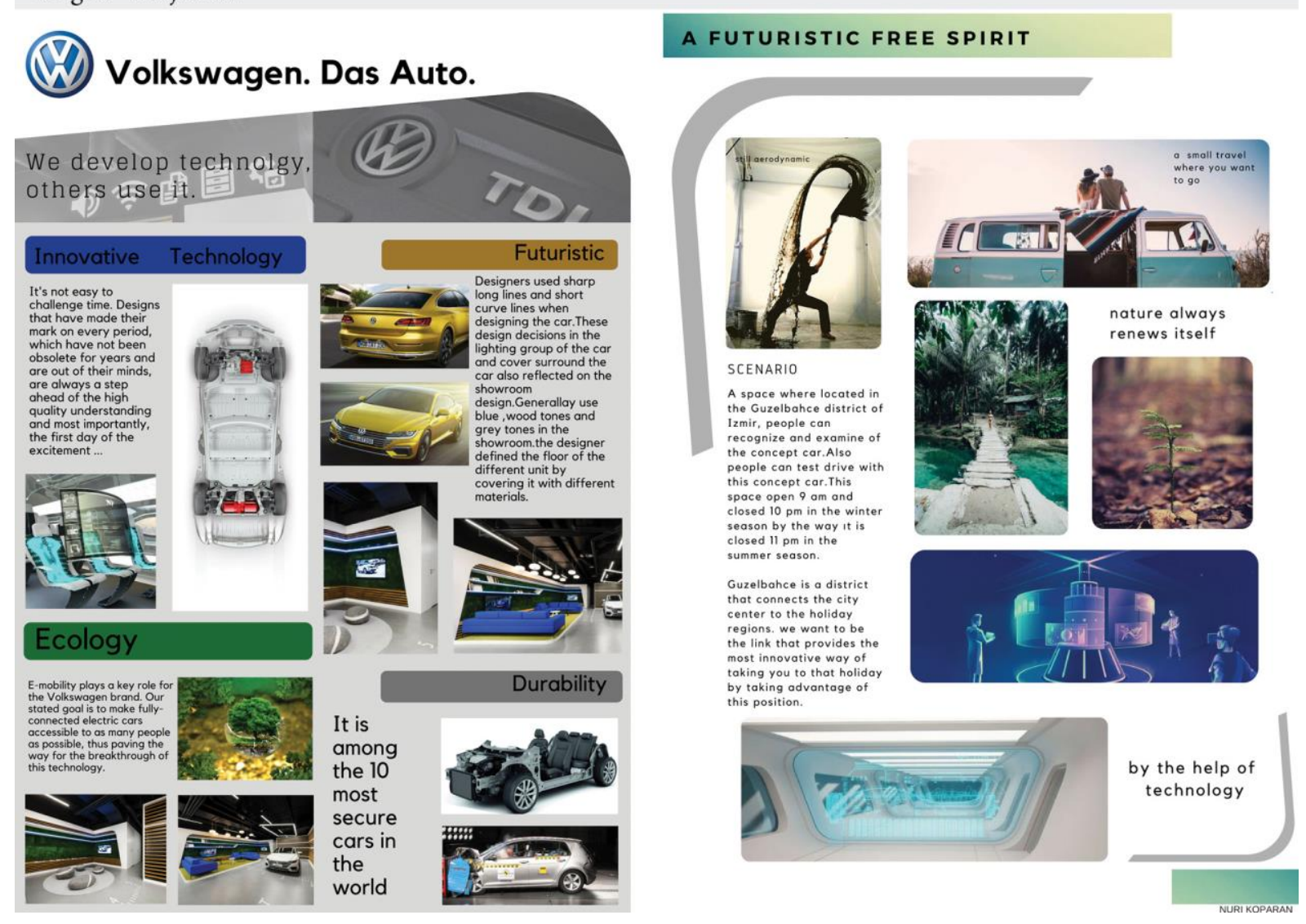

Figure 5 - Stage I - Project IV 


\section{Project $V$}

The concept was to embrace the eclectic style of the brand taking the customers - fashion and art lovers - at the core of the brand philosophy. Therefore, the design idea was to bring order within a complex system, where several functions take place. A variety of products, such as clothing, accessories, books, and food are sold along with a rich cultural environment. Retailing experience would be blended with art, culture, music, cuisine, and design from all around the world (Figure 6).

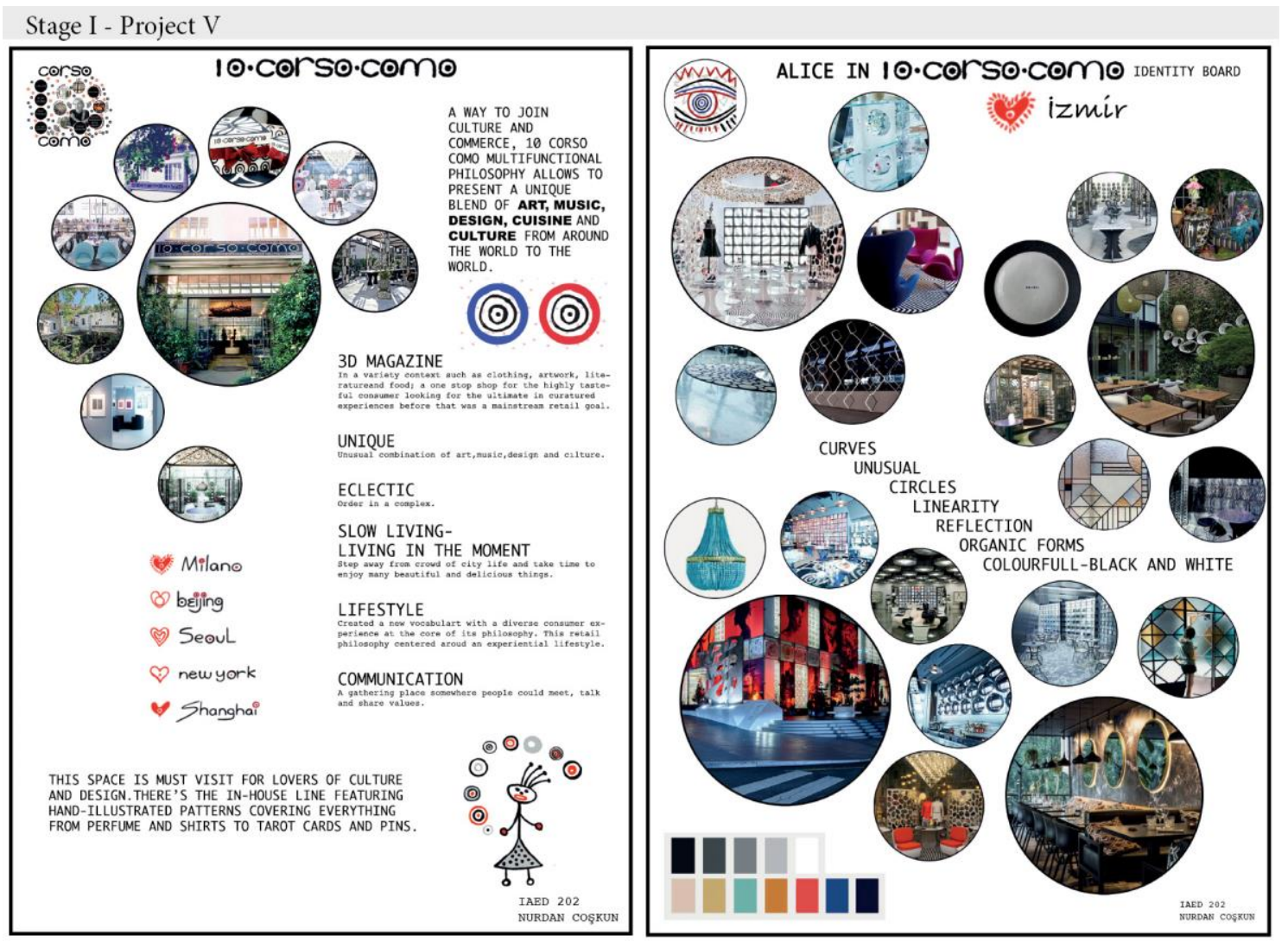

Figure 6 - Stage I - Project V

\section{Stage II: Spatial Development}

Stage II was the explorative study of the spatial layout based on design idea and scenario. The students were expected to achieve a volumetric understanding of the existing space, propose the relations of spaces and circulation, and set the foundations for the spatial development of their project by identifying public, semi-public, semi-private, and private functions within the whole space. 


\section{Project I}

In this stage, the spatial organization was developed with the idea of bringing nature inside the retailing space. Therefore, the student privileged the sea view and placed the water element at the centre of the space. Vegetation strengthened the decision to create a natural atmosphere. The spaces were distributed around a centrality that provided space definitions, but also a visu-al continuation. Public spaces were located on the ground floor and private or semi-public on the mezzanine to guarantee the necessary privacy, but also to maintain a visual and spatial tie with the whole space (Figure 7).

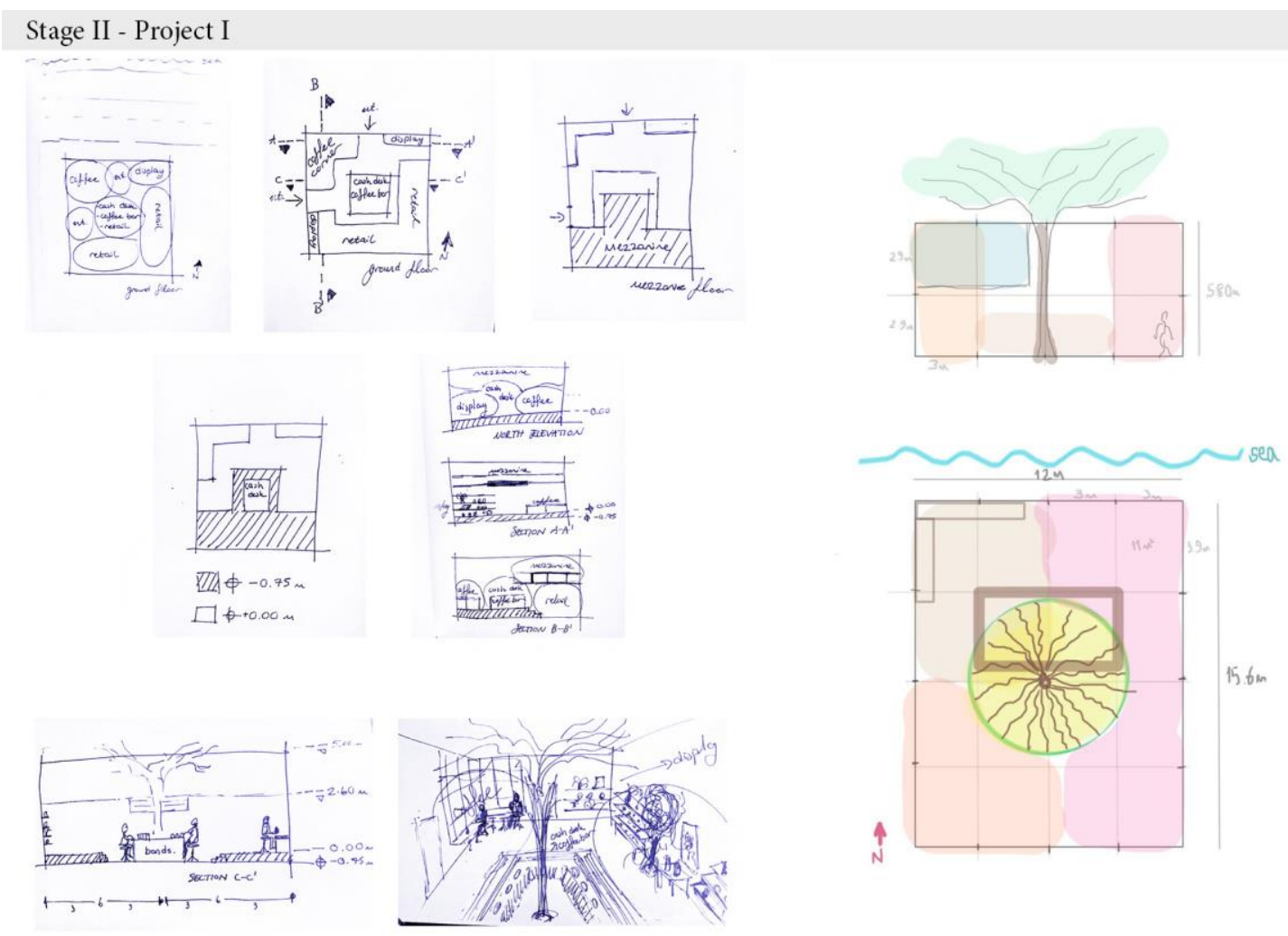

Figure 7 - Stage II - Project I 


\section{Project II}

According to the scenario, the display of products and the exhibition area were the focus in this project. Several versions of diagrams were studied. However, this function recurred to overlap with each other because the student's intention was to connect exhibitions and product display within the space. In addition, particular attention was given to the layout of the existing struc-ture to create references with the building (Figure 8).

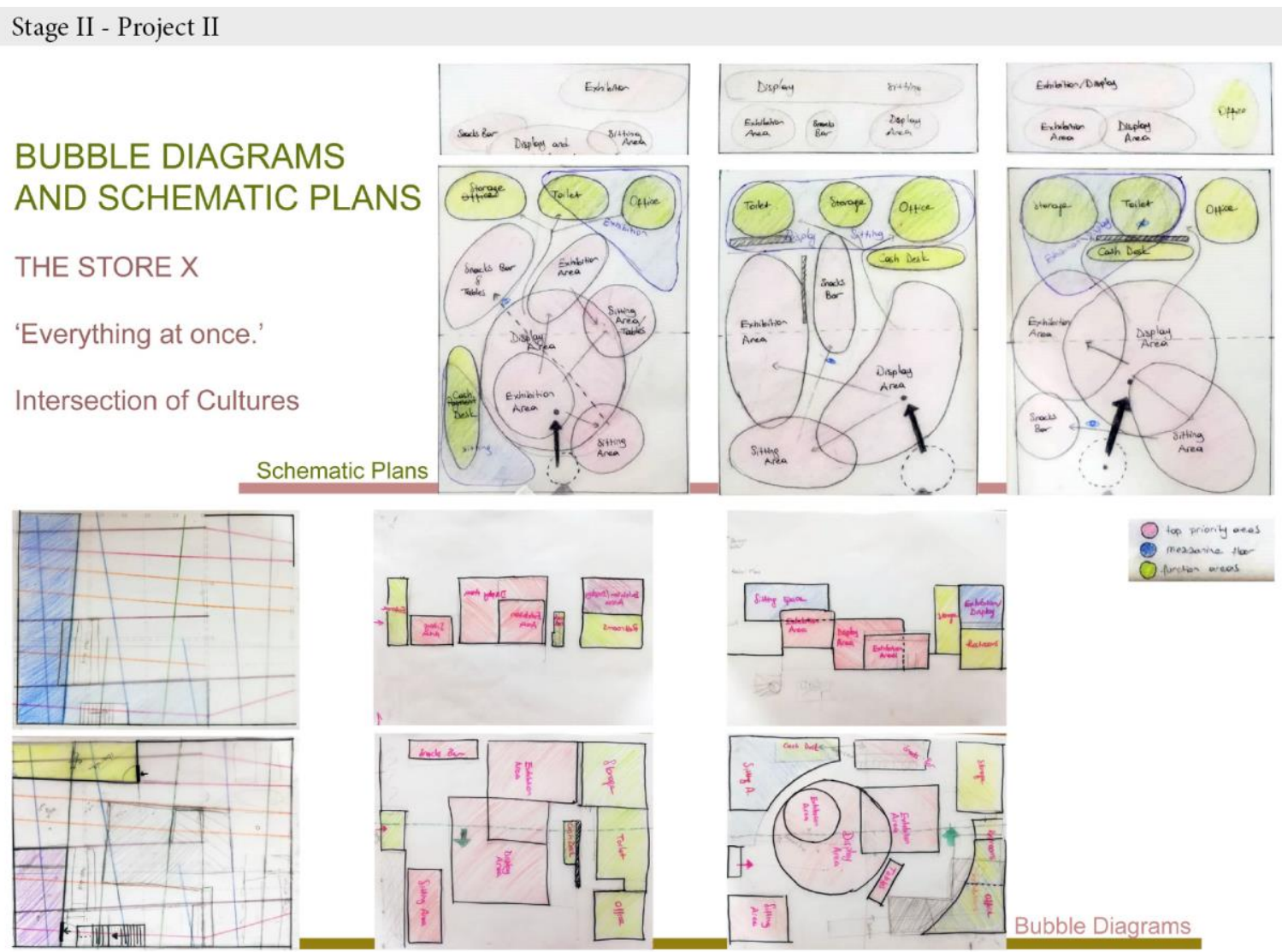

Figure 8 - Stage II - Project II 


\section{Project III}

An orthogonal layout was developed around a double high atrium, which was allocated as temporary art and fashion exhibition area. This space was surrounded by stairs that worked as physical connection between the ground floor and the mezzanine floor. This solution would allow the visitor to engage with the exhibition from multiple perspectives (Figure 9).

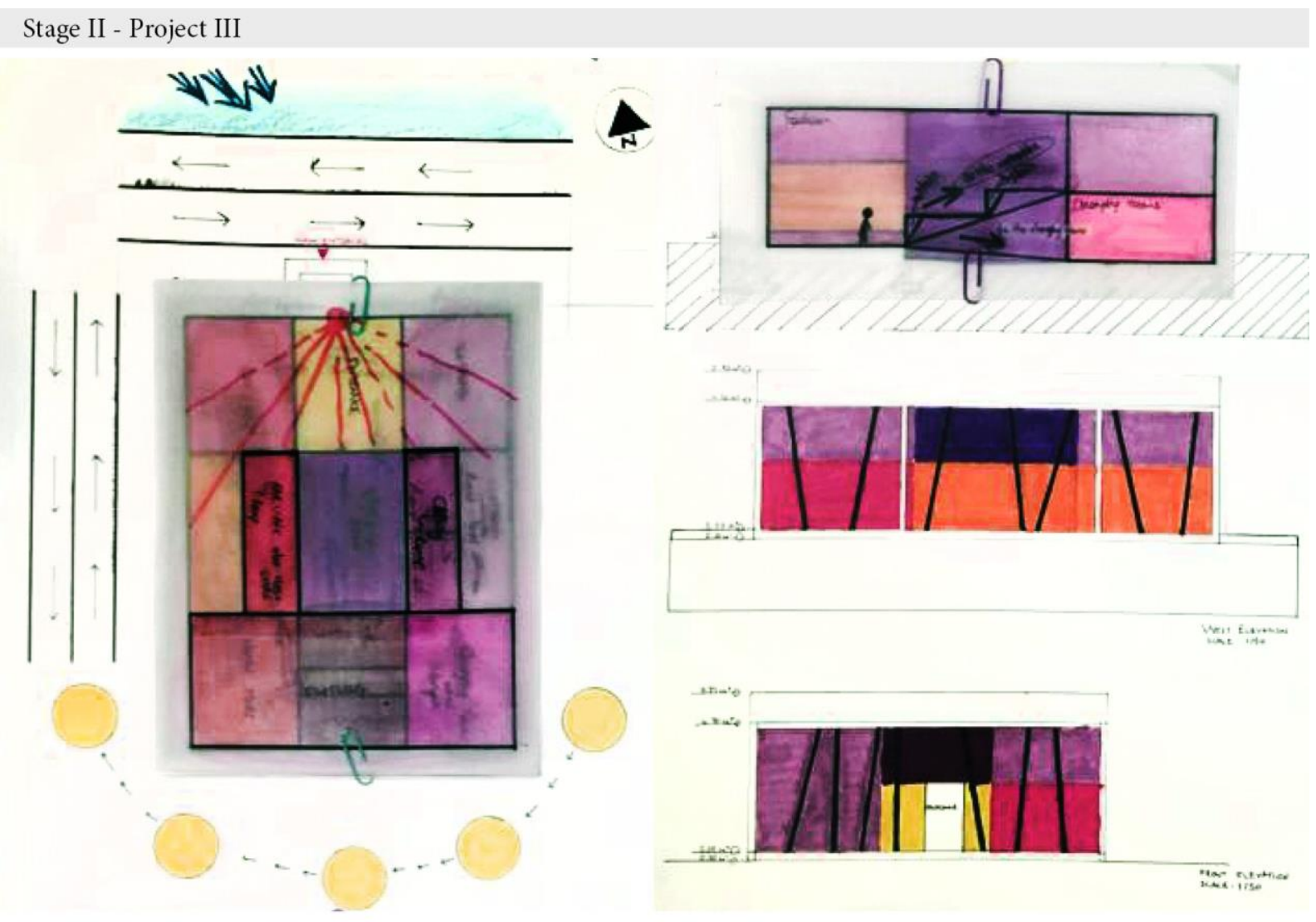

Figure 9 - Stage II - Project III 


\section{Project IV}

As the prototype of the car was the main element to be exhibited, the layout of the third project was designed to emphasize the object and to create different points of observation. All the oth-er functions were located accordingly in a hierarchical manner. Visual access of the product, both from outside and from inside, was one of the main concerns. Indeed, its placement took advantage of the wide windows and the main entrance. The functions were defined with level differences (Figure 10).

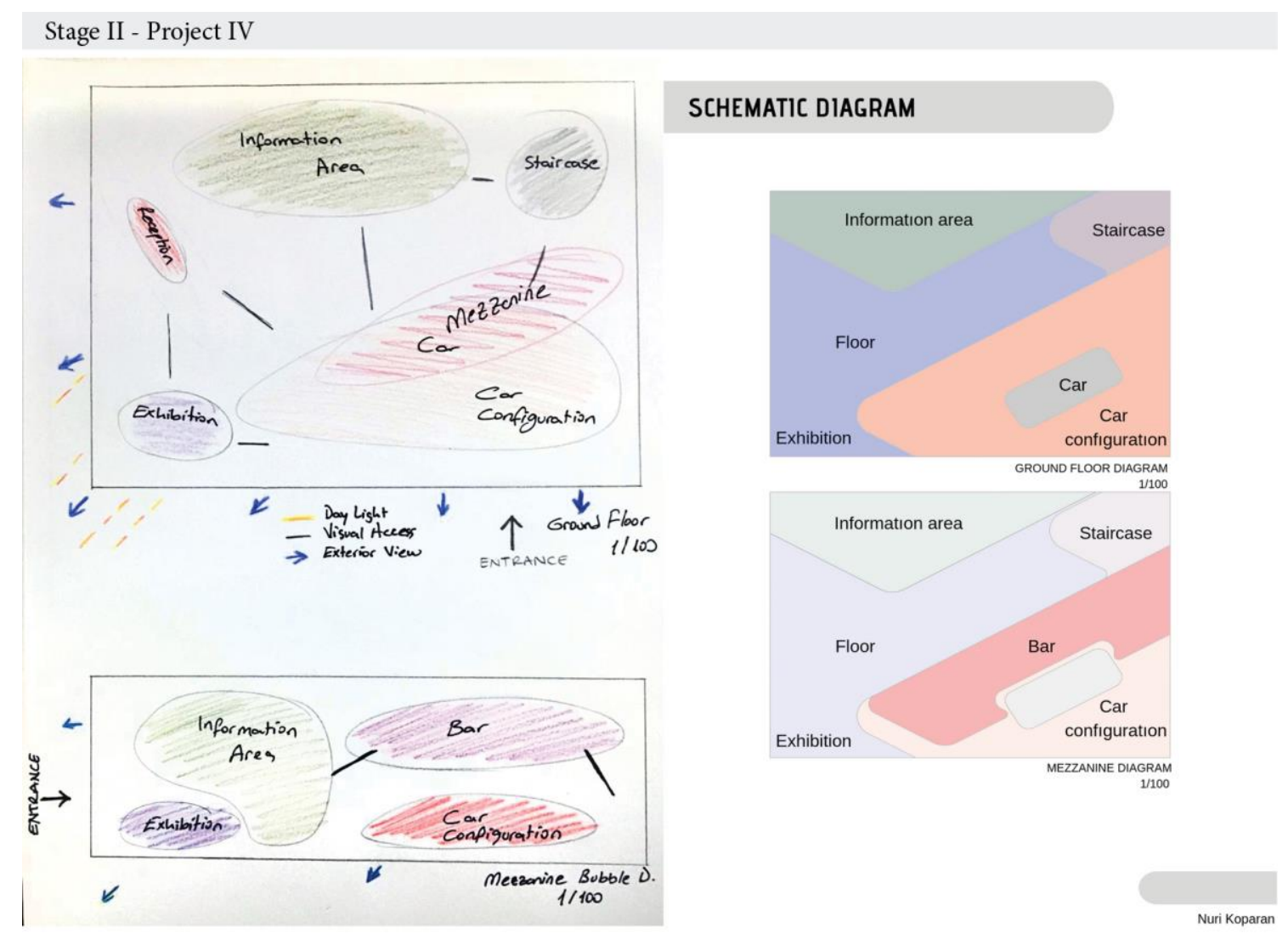

Figure 10 - Stage II - Project IV 


\section{Project $V$}

The layout of this project was organized around the space for temporary events. A radial system was created to bind different functions with the core of the project. The staircase that enclosed the temporary events established a physical and visual relationship between the two floors. All the elements were defined according to the centre of the main space (Figure 11).

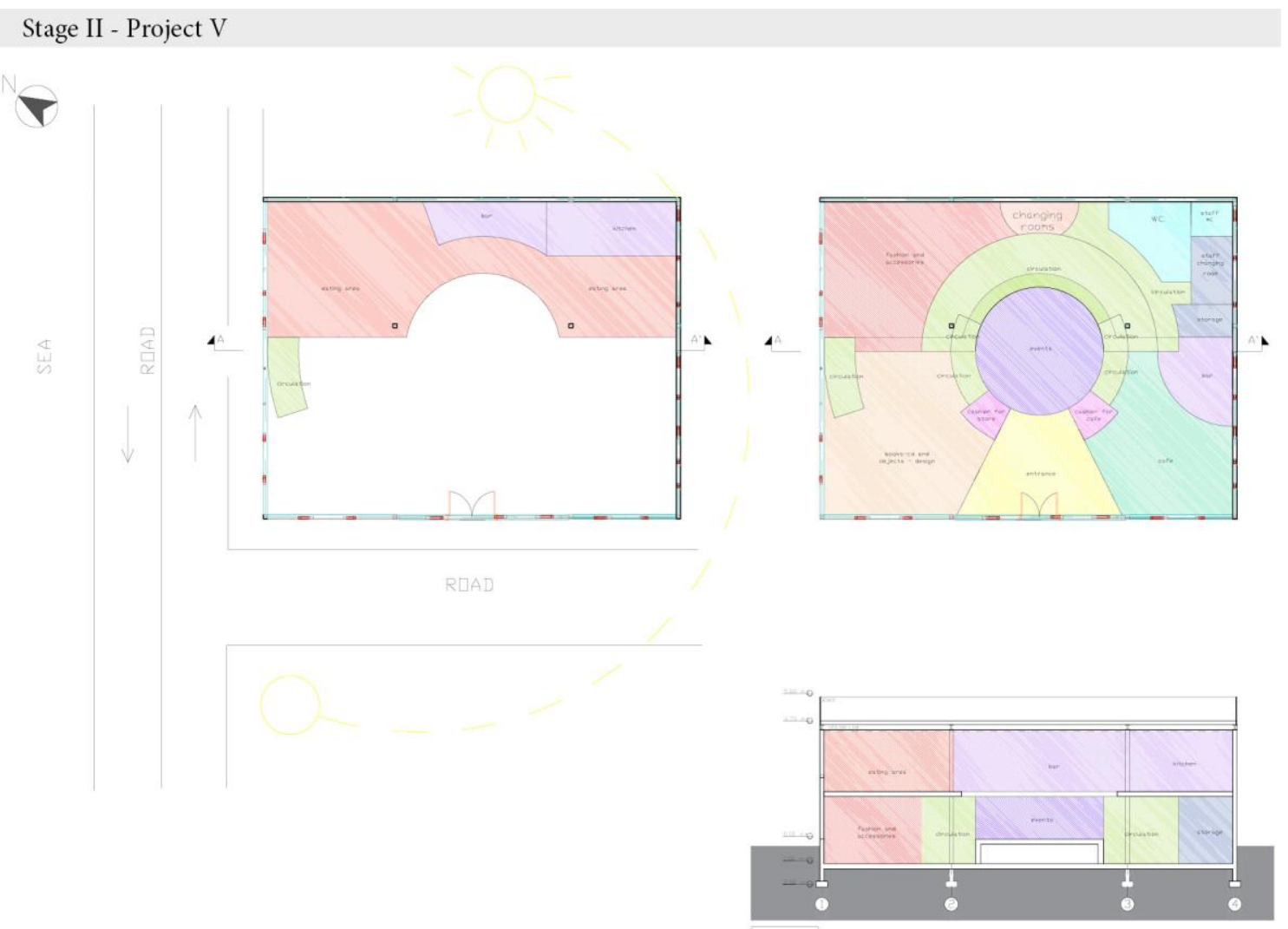

Figure 11 - Stage II - Project V

\section{Stage III: Technical Drawings and Model}

In Stage III, the students elaborated the initial design concept and related decisions into a more advanced design solution. With the construction of the physical model, they analyzed and interpreted their concept and design decisions in the three-dimensional space. This was the stage where earlier abstract decisions were materialized. 


\section{Project I}

More information was added to the technical drawings, such as materials selection and colours. A combination of wood surfaces and metal structures was mostly employed to recall the theme of nature and the urban lifestyle. The model was built to analyse the volumes and to better un-derstand the relationship between exteriors and interiors. The façade, shop window, and sky-light were designed to screen direct sunlight to let the natural light illuminate the space during the daytime (Figure 12).

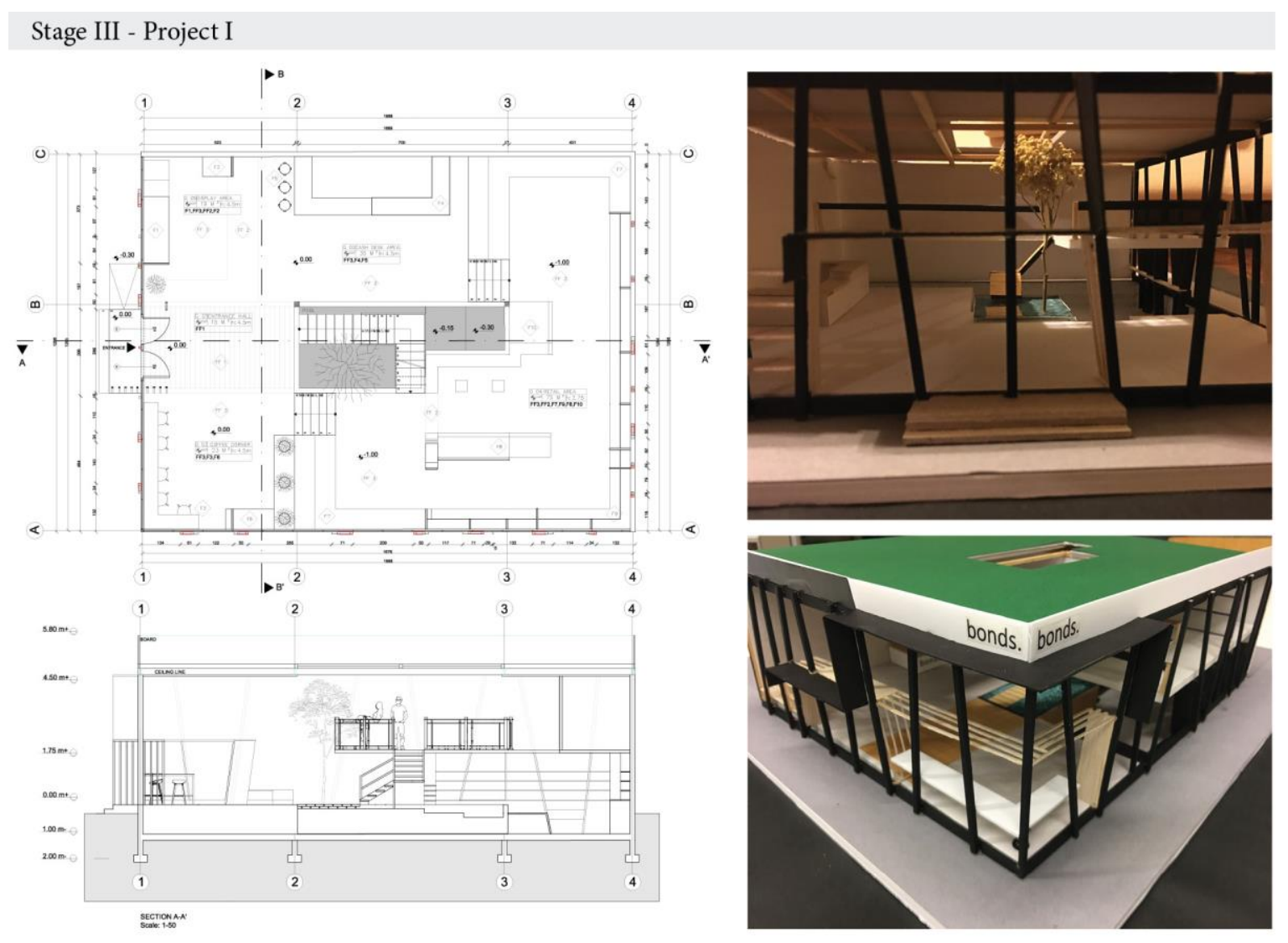

Figure 12 - Stage III - Project I 


\section{Project II}

At this stage, it became more evident that the idea of the student was to develop a series of spaces in continuation. A twisting space was shaped by vertical connections, which bind differ-ent levels both physically and visually. The inclined wall was designed in the section to install a common language with the façade and to obtain more dynamism. The model emphasized the spatial relations and volumes (Figure 13).

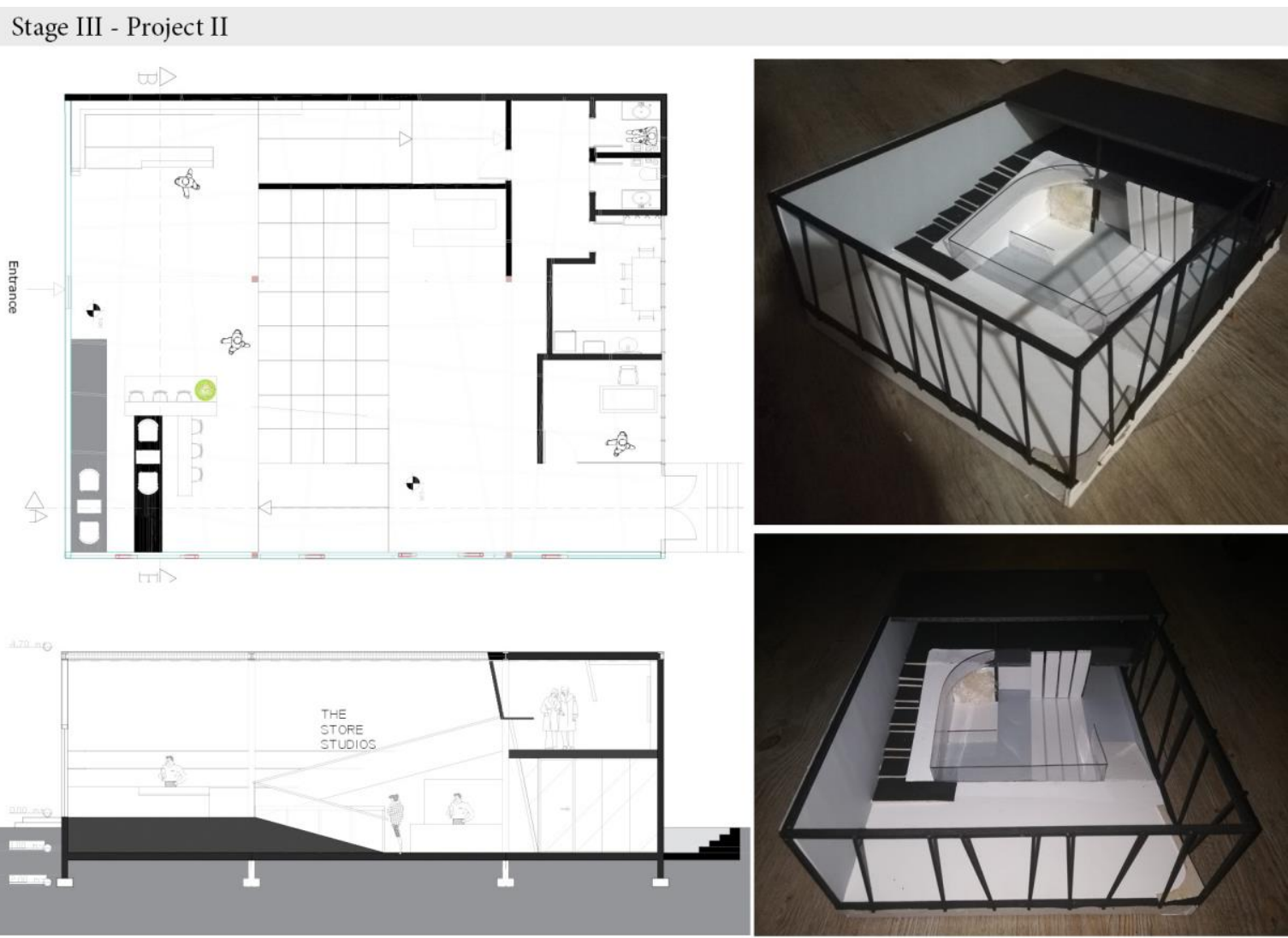

Figure 13 - Stage III - Project II 


\section{Project III}

Model and drawings showed the relation between the atrium for exhibitions and the other spaces, which were organized by function. Fixed furniture was placed accordingly. The store window was used to display selected products of the collection to attract the attention of the passers-by (Figure 14).

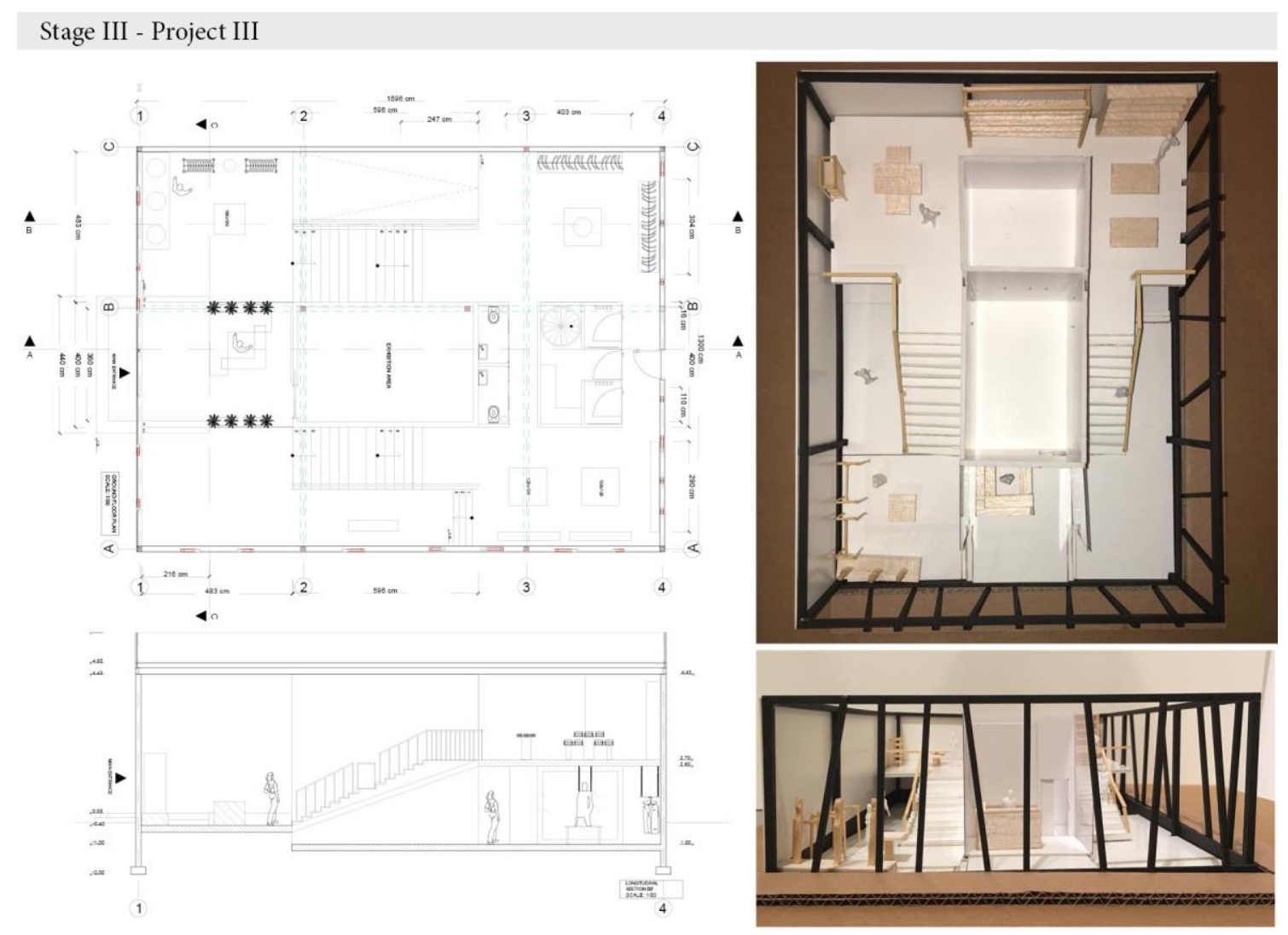

Figure 14 - Stage III - Project III 


\section{Project IV}

The project was developed along a rotated axis in order to create a dynamic environment. This solution was also used to take advantage of the perspective from the road. The language was contemporary, and the lines were inspired by the form of the car. Emphasis was put on the logo of the brand, as the aim was to design a space that was aligned with the corporate identity. Therefore, colours and materials were selected accordingly (Figure 15).

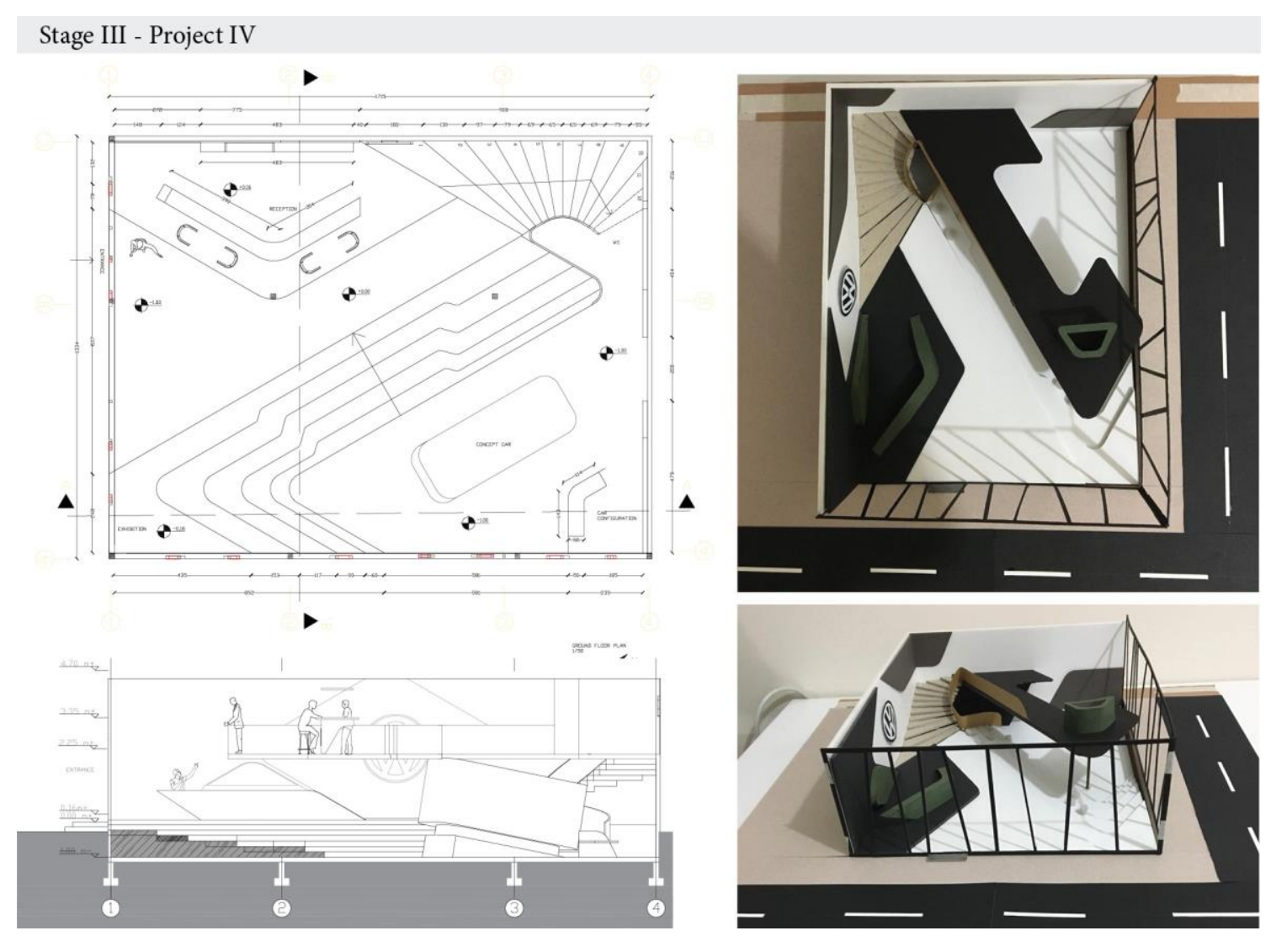

Figure 15 - Stage III - Project IV 


\section{Project $V$}

Space was organized by the radial distribution of functions. Each sector was generated by one centre and invisible lines become evident with the use of different flooring materials, space distribution, and typology of exhibited products. This design solution was strengthened by a circular circulation on both levels and by furniture design (Figure 16).

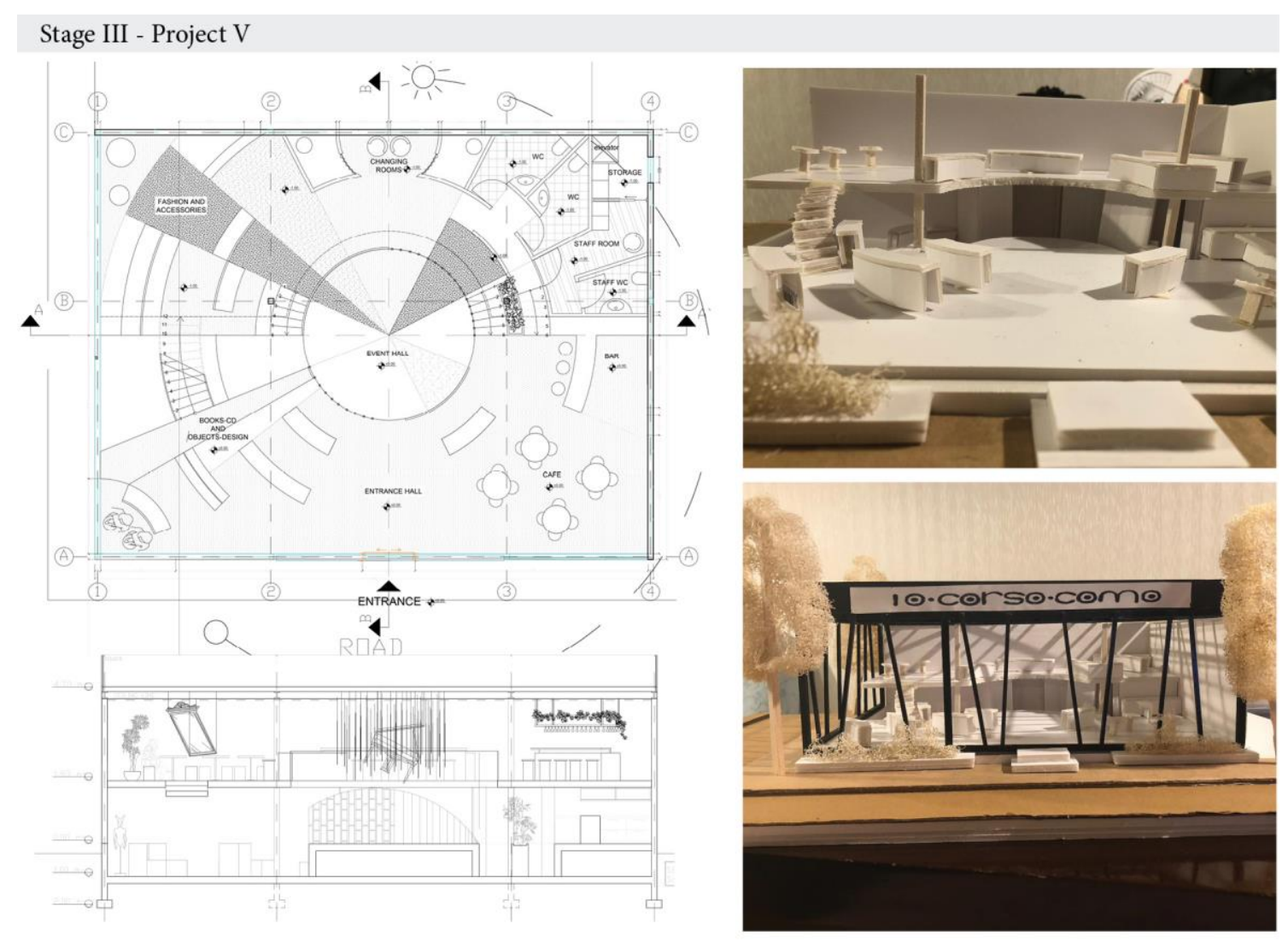

Figure 16 - Stage III - Project V

\section{Stage IV: Detailing and Three-dimensional Representation}

Stage IV was necessary to develop design decisions into feasible solutions at a smaller scale, working on material connections and details. Furthermore, a digital model and sketches of the space was produced by the students to obtain interior views of the designed space and to envision the project three-dimensionally. 


\section{Project I}

Detailing was specifically crucial for this project. The student worked on many space-saving solutions for storing the products on sale and furniture was designed expressly for the space to achieve a consistent design language. For lighting, spotlights were preferred because of flexibility. Sustainable materials were selected to strengthen the ideology of the brand in the project (Figure 17).
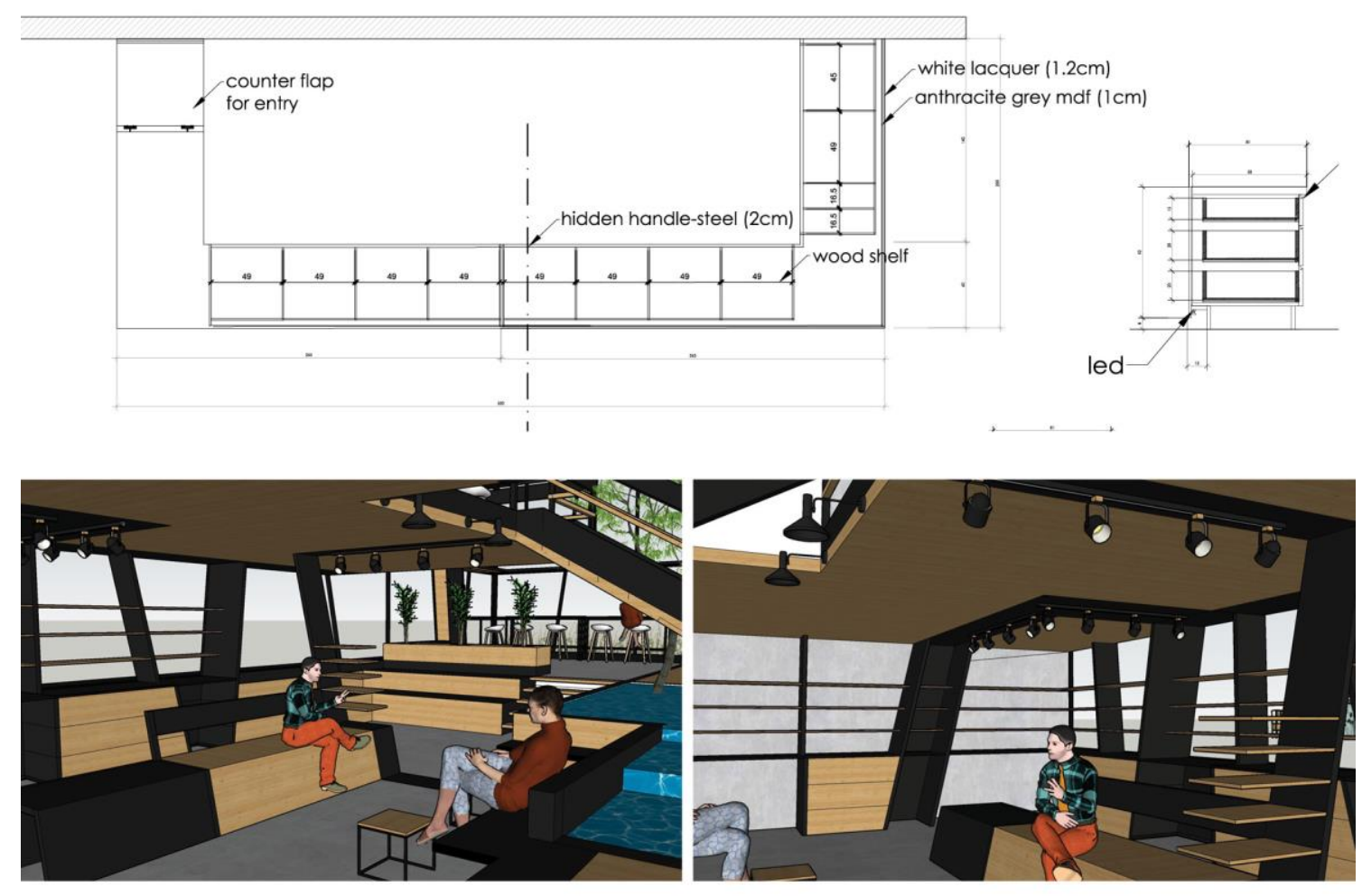

Figure 17 - Stage IV - Project I 


\section{Project II}

A consistent work was developed for lighting solutions integrating daylight and general lighting. For display areas, additional lighting was provided to emphasize the objects within their context. Furthermore, fixed furniture accommodated lighting solutions according to their function (Figure 18).
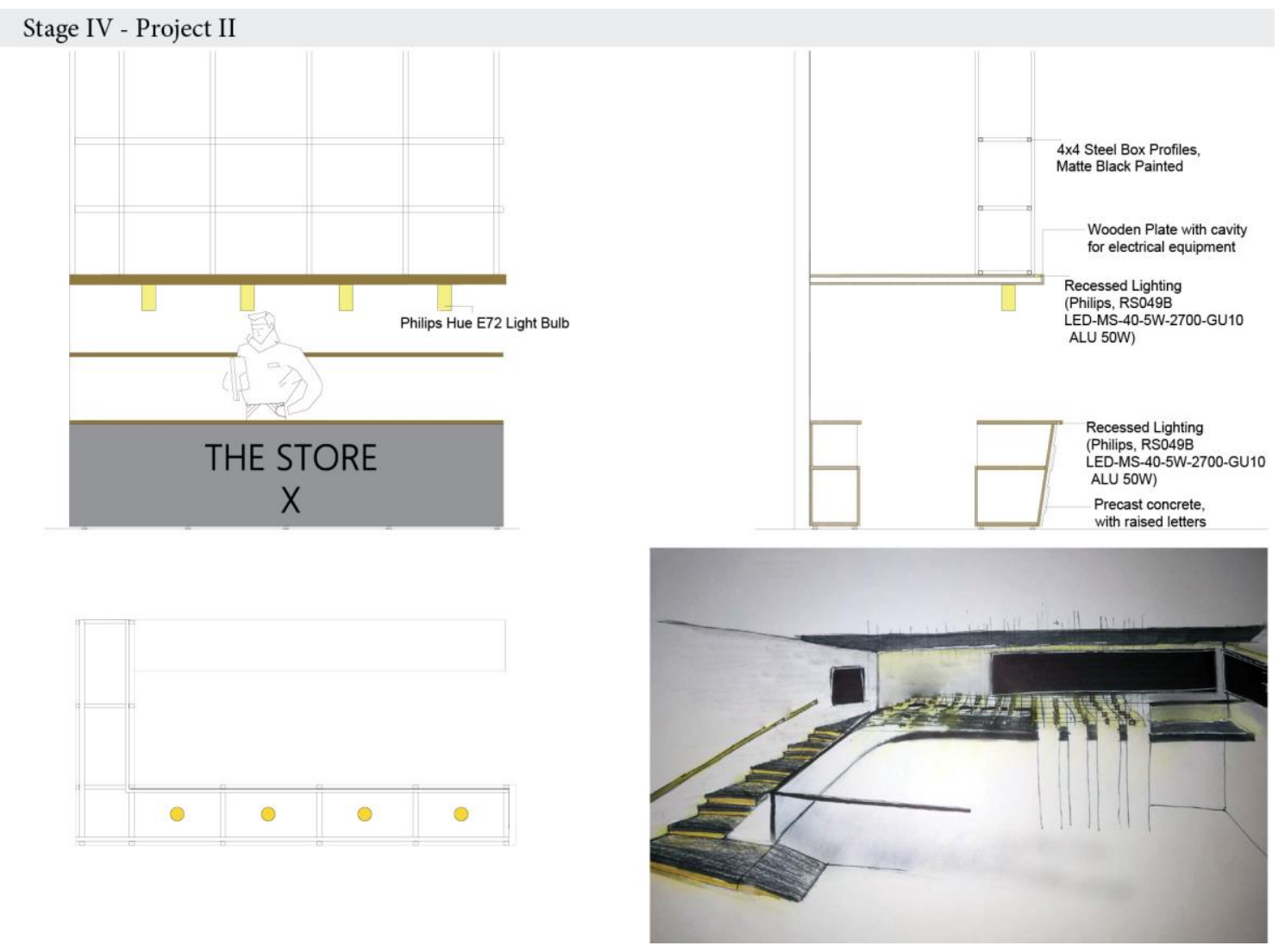

Figure 18 - Stage IV - Project II 


\section{Project III}

The student worked on fixed furniture detailing. The furniture, due to the material selection and types of materials assembly, confer to the project an industrial language. A consistent design approach was used for the whole space. Metal profiles were used as both structural elements for objects display and decorative elements (Figure 19).

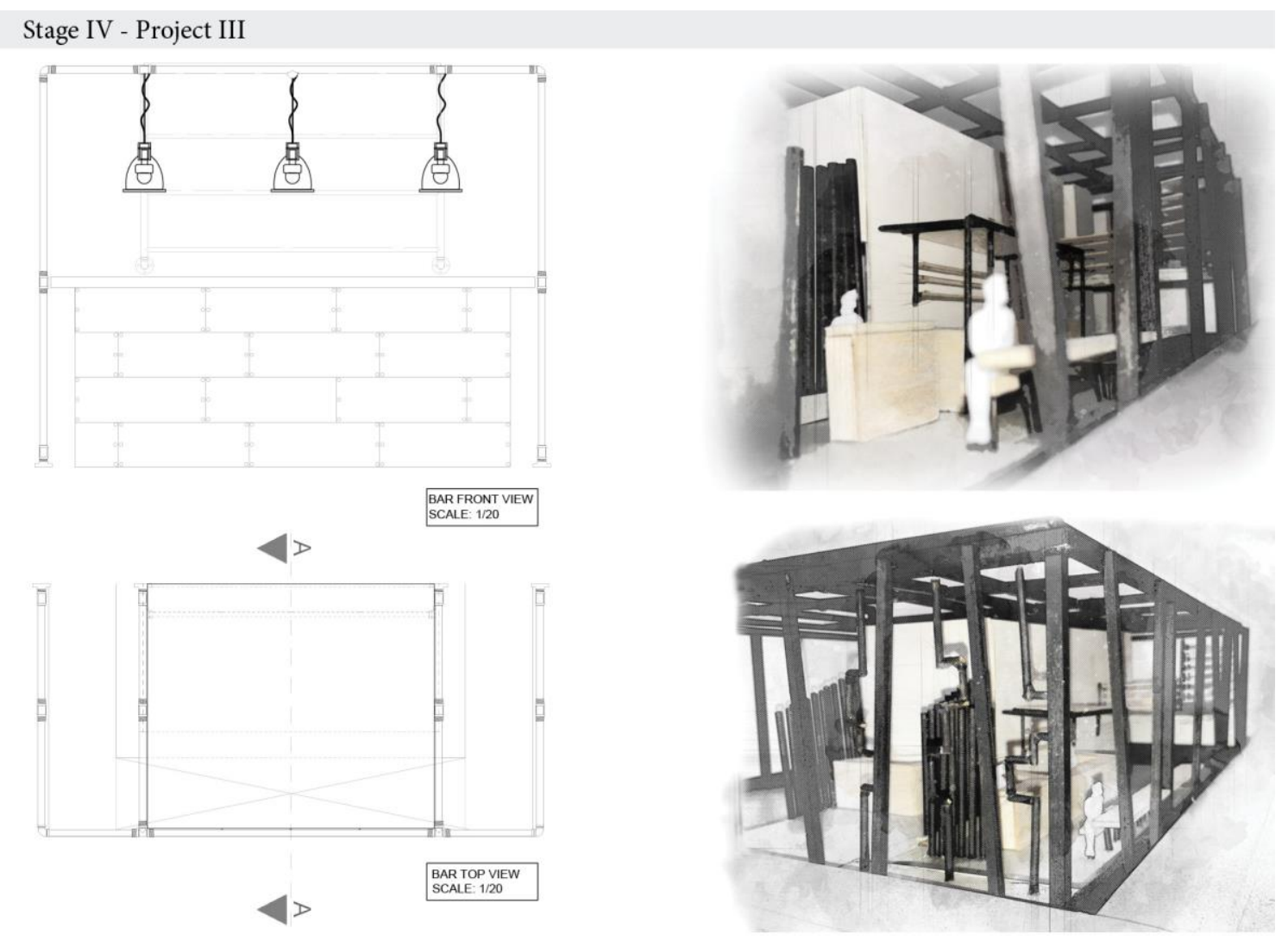

Figure 19 - Stage IV - Project III 


\section{Project IV}

The colour selection scheme was confined to just a few in order to emphasize the car. Details of material assemblies were combined to give a minimal look to the space. A limited amount of merchandise was exhibited, so the product had to be stored in cabinets that were designed to be integrated with the interiors. Lighting elements were used to accentuate spaces and level differences (Figure 20).

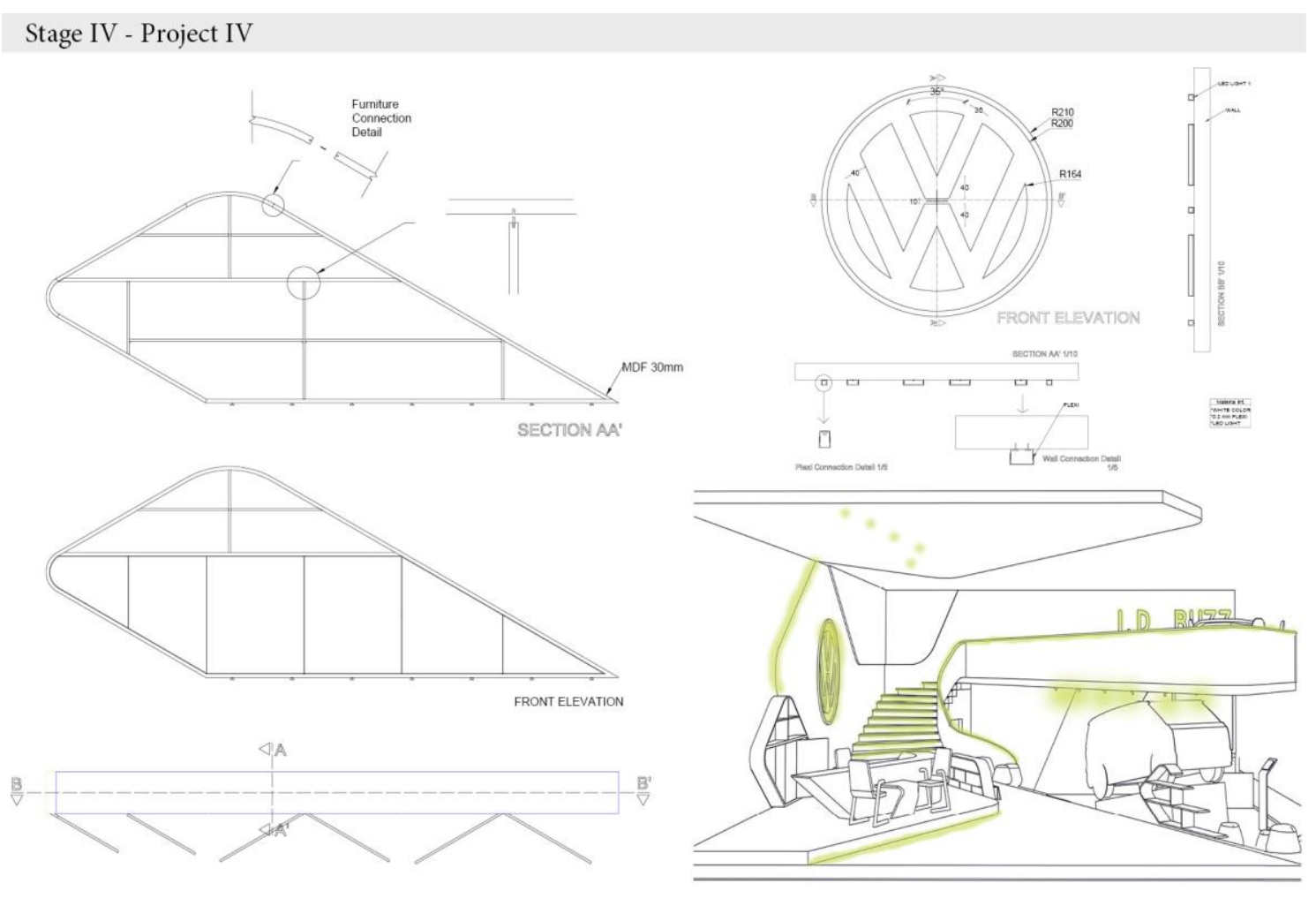

Figure 20 - Stage IV - Project IV 


\section{Project $V$}

In this project, materials, textures, and colours selection were particularly important to represent a sense of unity and balance to the overall composition and to reflect the brand identity. Different solutions were used to stimulate the senses. However, a unified design language and details were created both for the whole space and for the subspaces, in which different characteristics were associated with the function (Figure 21).

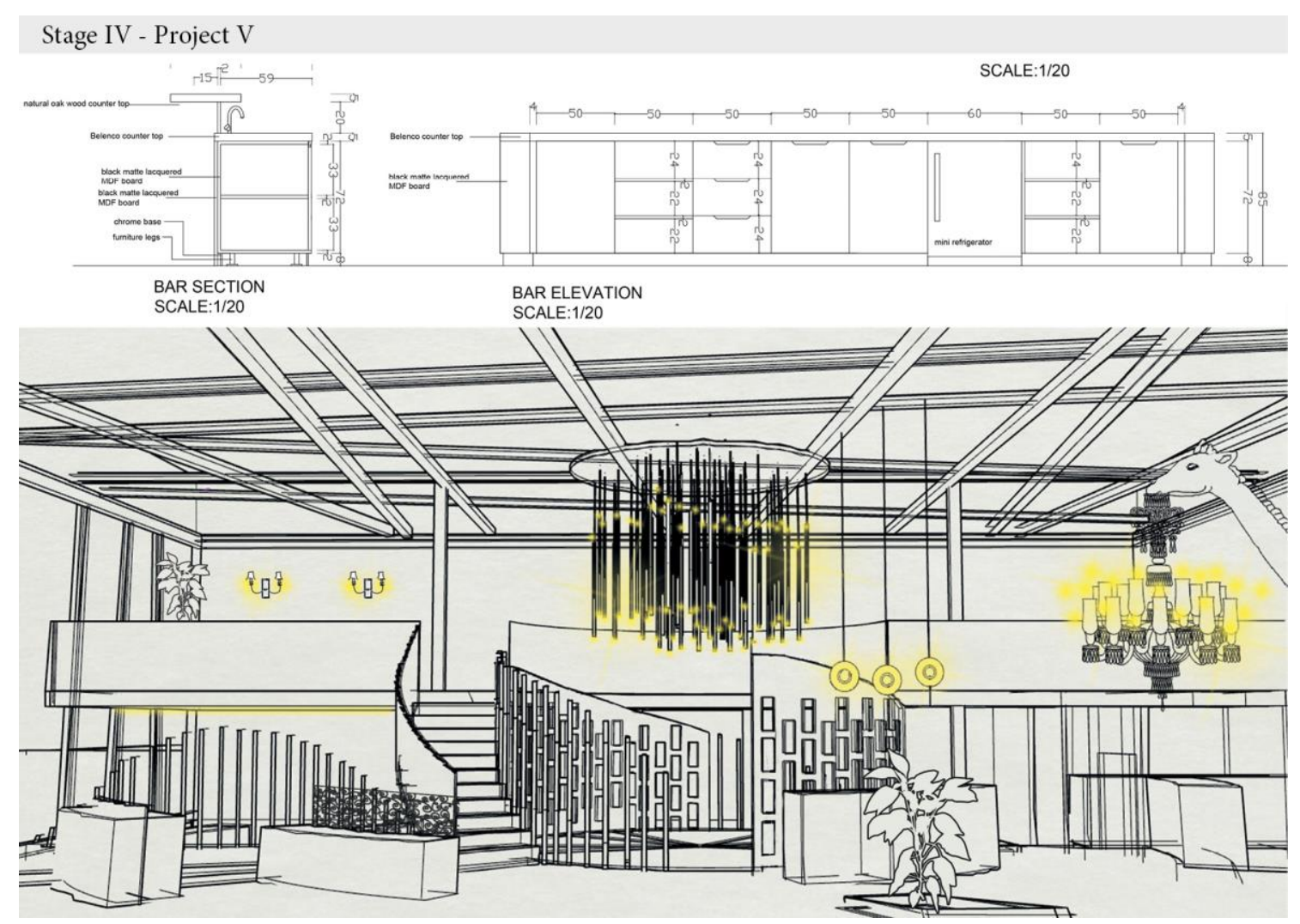

Figure 21 - Stage IV - Project V

\section{Stage V: Finalization}

At the final stage, the students were to complete the project as a whole and finalize the design process. Particular attention was given to the presentation of the project and the effective communication of the main design idea. Feasibility of the project and the success of the student in carrying an abstract idea formed at the beginning of the process to the final stage was a key criterion for this stage. 


\section{Project I}

The student was able to summarise efficiently all the design process, first introducing brand, users, and site, and then presenting his design ideas with keywords and with brief explanations of his concept. Interior and exterior views together with technical drawings convey the design ideas and the atmosphere of the space (Figure 22).

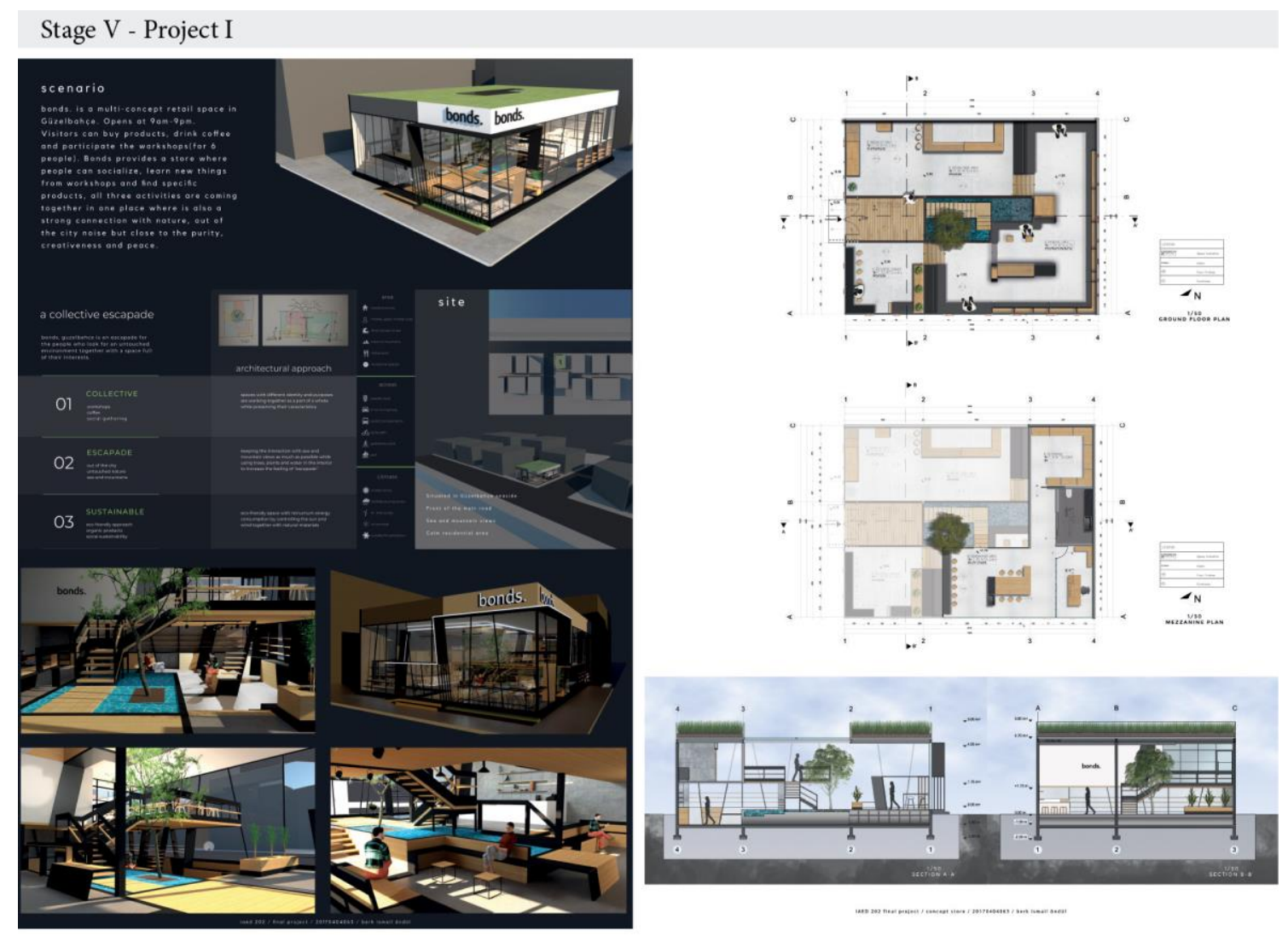

Figure 22 - Stage V - Project I 


\section{Project II}

The student presented the project first introducing the brand, and then explaining the concept for Güzelbahçe store. Visual references and interior views of the project were combined to illustrate the design idea. Because the building affected some interior design decisions, a structural diagram of the building was included in the presentation (Figure 23).

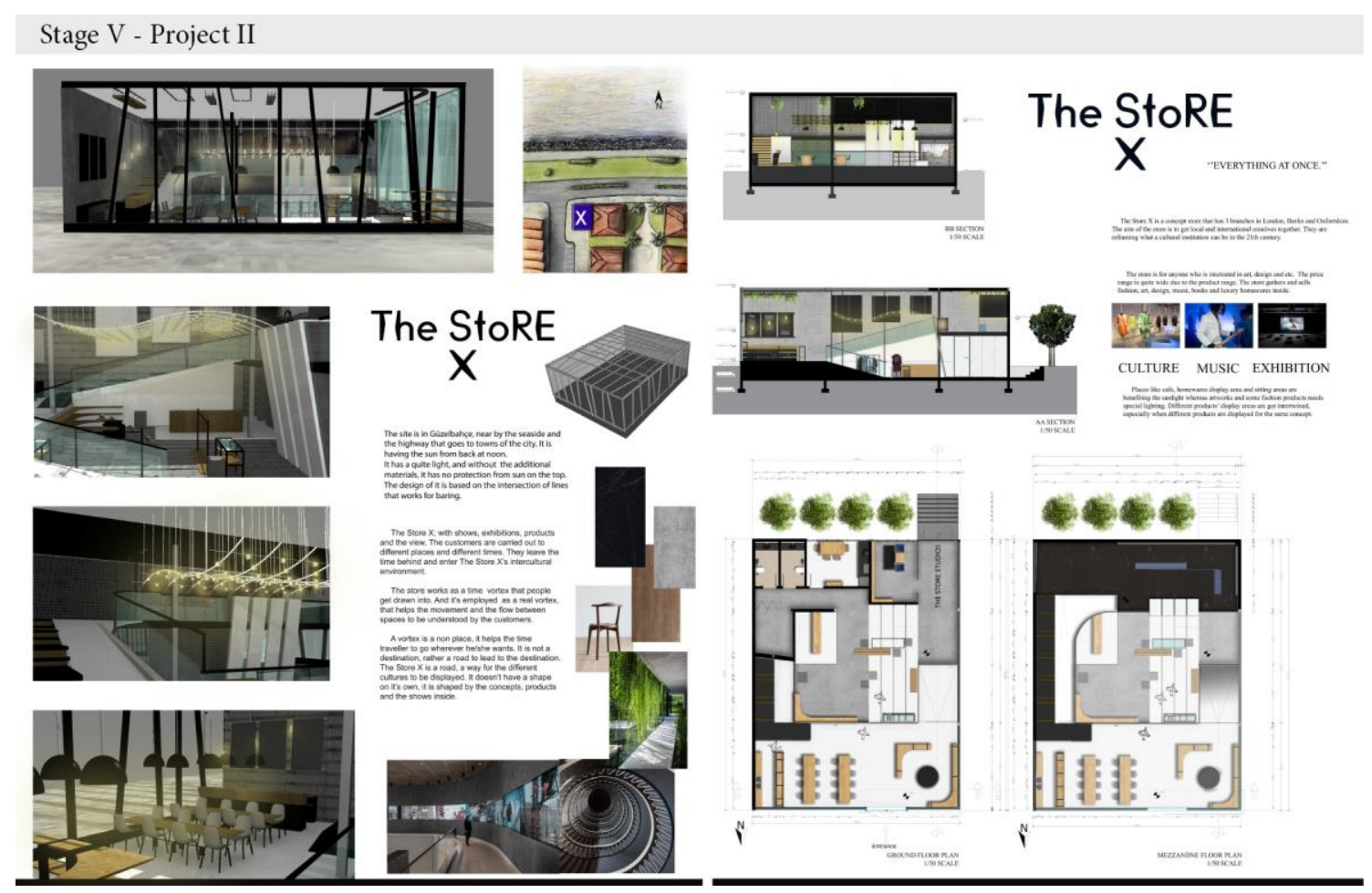

Figure 23 - Stage V - Project II 


\section{Project III}

An articulated analysis of the site, scenario, and brand was given to explain the design decisions. The technical drawings were detailed, communicating the atmosphere of the space (Figure 24).

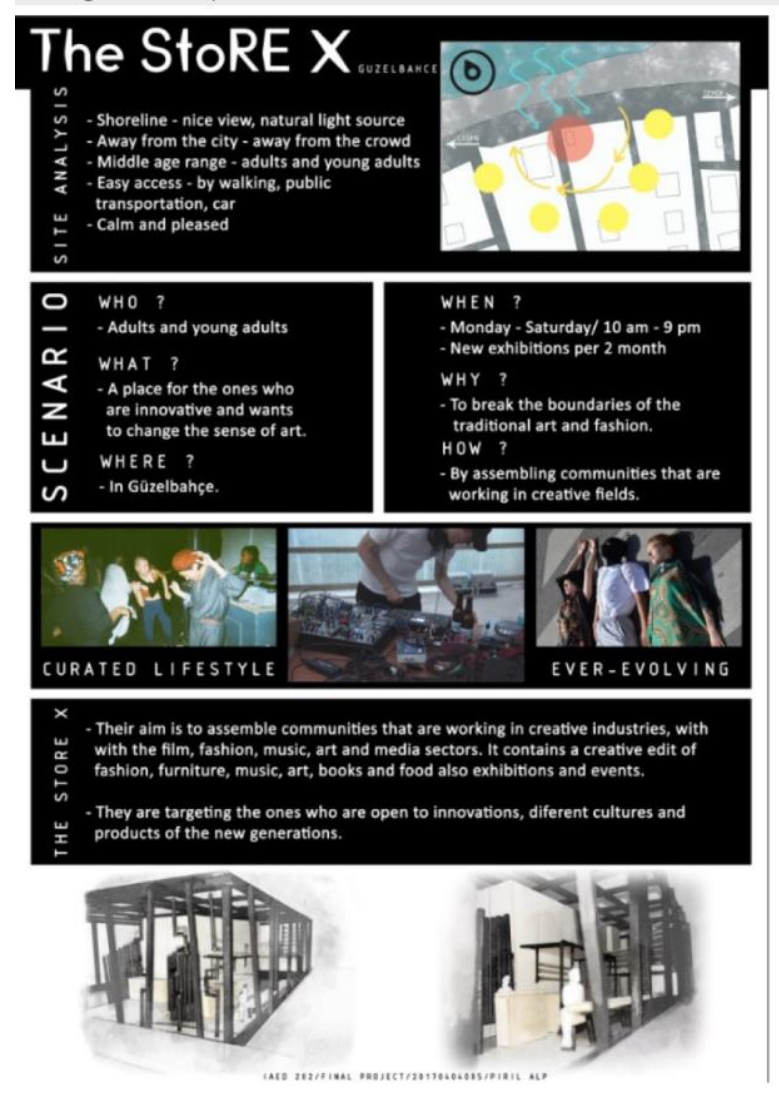

\section{The StoRE $X_{\text {nanuma }}$}
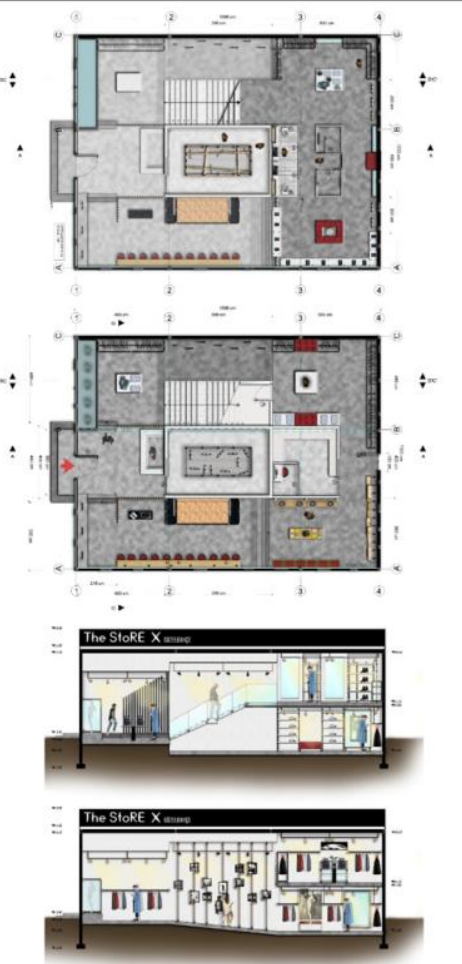

Figure 24 - Stage V - Project III 


\section{Project IV}

The final presentation of the fourth project was aligned with the concept of the store and the brand. Colour selection and language of the interiors were consistently reminded in the presentation board (Figure 25).

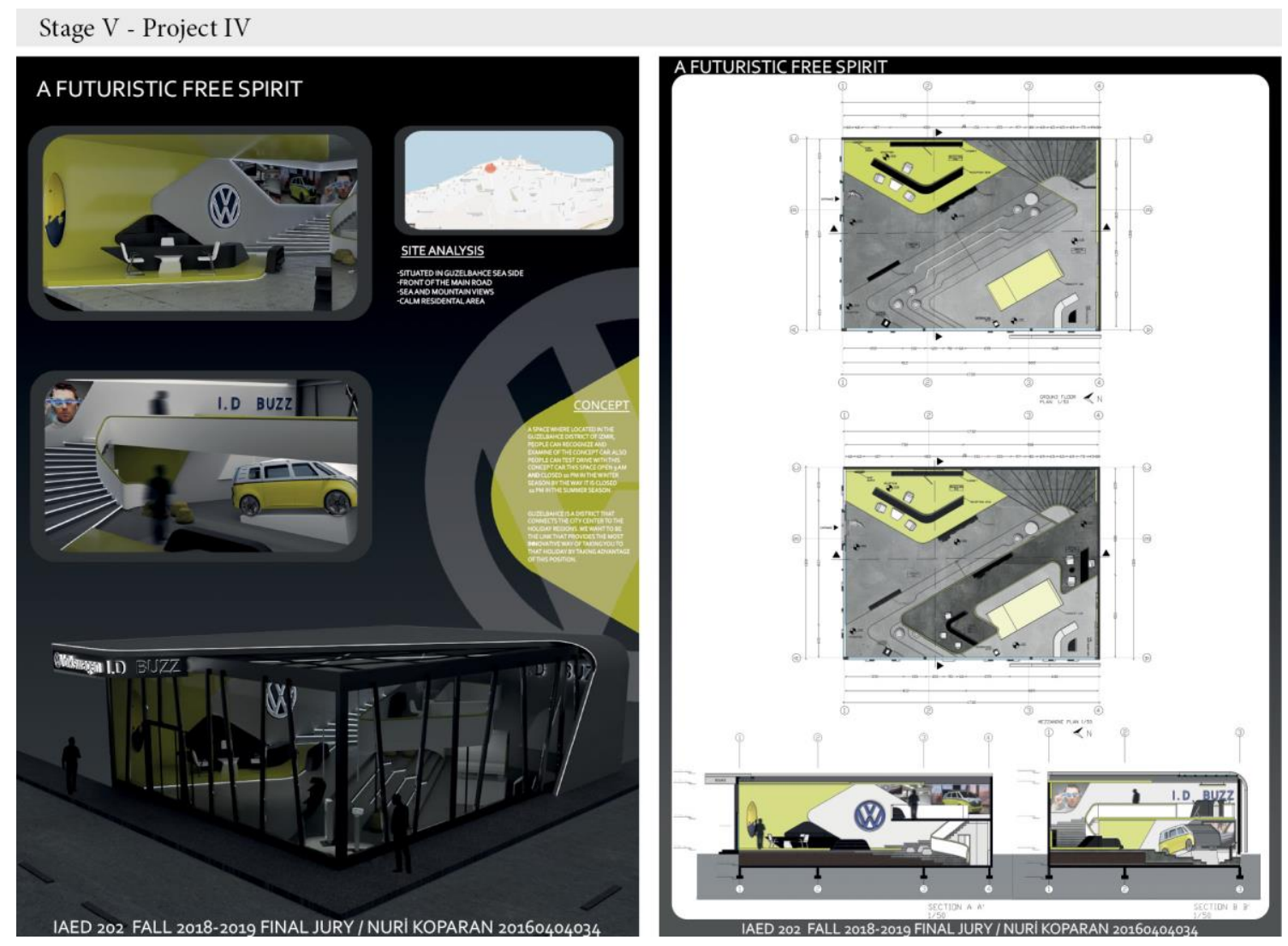

Figure 25 - Stage V - Project IV 


\section{Project $V$}

Detailed explanations of brand, site, concept, and scenario were associated with imagery and keywords to explain the design decisions. Interior perspectives from various spaces, such as public areas and circulation, were taken to express the design idea (Figure 26).

Stage V - Project V

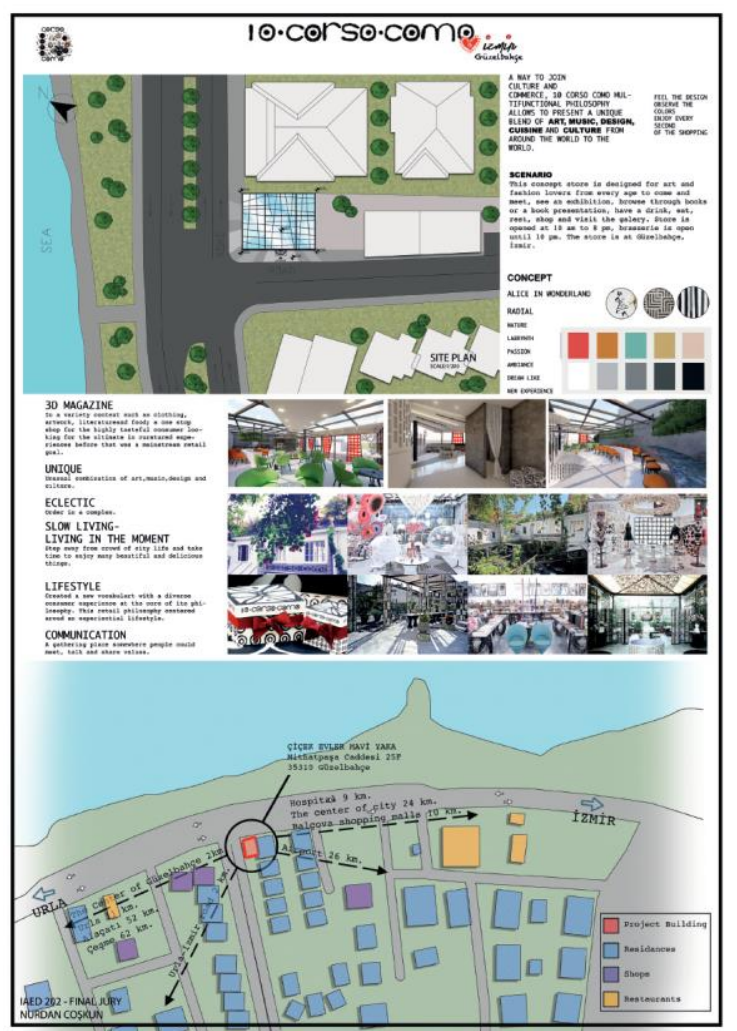

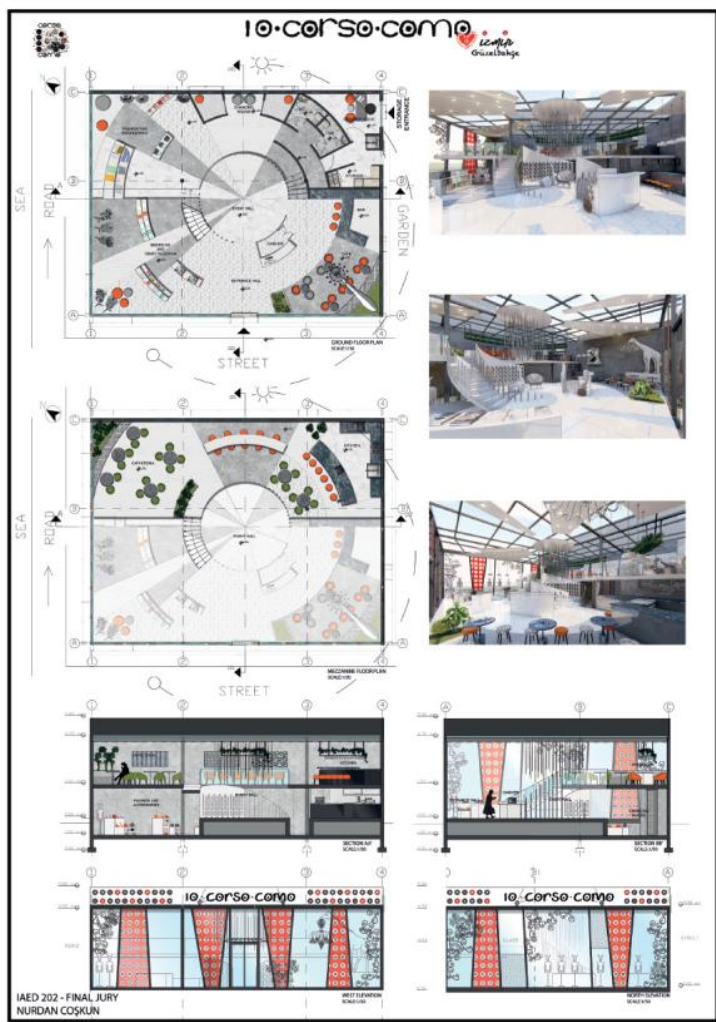

Figure 26 - Stage V - Project V

\section{DISCUSSION}

During the first stage, the students developed a meticulous research to identify the problem and the necessities of a concept store. This has allowed them to understand the problem and to draft a detailed scenario and concept. As Simon (1969) argues, the design process is a succession of critical decisions that lead to a response at a well-defined problem and research is fundamental for understanding of the problem and engage with the design process.

Furthermore, the interdisciplinary approach of combining interior architecture with retailing issues has been beneficial. This approach has encouraged the students to research an area that was not familiar to them and to find the necessary resources to feed the design with significant contents. Students had learned to develop design ideas based on information, such as brand identity, user profile, retailing design, and concept store. Understanding such issues is fundamental for the development of a rigorous design thinking, able to combine inputs coming from the case study and 
the own analysis, which was based on the urban and social fabric of the con-text. Such approach has resulted effective to develop cognitive and creative thinking of the students. Goodrich (2018) argues that experiential knowledge and practice mutually support each other in education and as Boradkar (2010) states, interdisciplinarity can be described as a form of knowing, acting, and thinking.

In the second, third, and fourth stage, the students gave a form and created a language for the interior space according to their scenario and concept. Abstract drawings, annotations, and diagrams were the tools adopted to organize the ideas and to transfer an abstract idea into a practical output that answer the design problem. As Herbert (1988) explore in his study, the development of a design solution is derived by continuous evolutions in the designer cognitive experience, which increase of complexity. Through study drawings, designers are able to express a mental process in a graphical manner. Sketching is necessary for the designer at the cognitive level. Graphics are an intrinsic part of the design process and a necessary tool for the designer to convey ideas in the studio (Ching, 1985; Miller, 1982). In each stage, the students have experienced different scales. Thus, the student could understand and compare the quality of information that each scale carries within itself.

Adopting multiple visualization tools within the whole design process has been beneficial to form and express efficaciously design ideas. Indeed, usually, sophomore students' three-dimensional understanding of the space and representation skills are still not totally developed. This method has allowed the experimentation of multiple tools and the integration of them along the design process. Besides, students have developed craftsmanship, sketching techniques, and got accustomed to new programs for representation. In the final stage, the students brought together the whole process in an exhibition format to be presented to instructors, peers, and external jury members. The representation has become a tangible product that is de-signed to disseminate ideas (Greenstreet \& Shields, 1988).

The structural organization of the semester into stages was successful in pacing the project development and in the clarification of the overall design process. This linear process provided the students to metabolize the objectives of each stage and improve their time-management skills. The following year, the same students reported that the acquired method supported them in overcoming the new challenges of the third-year studio (Figure 27). 


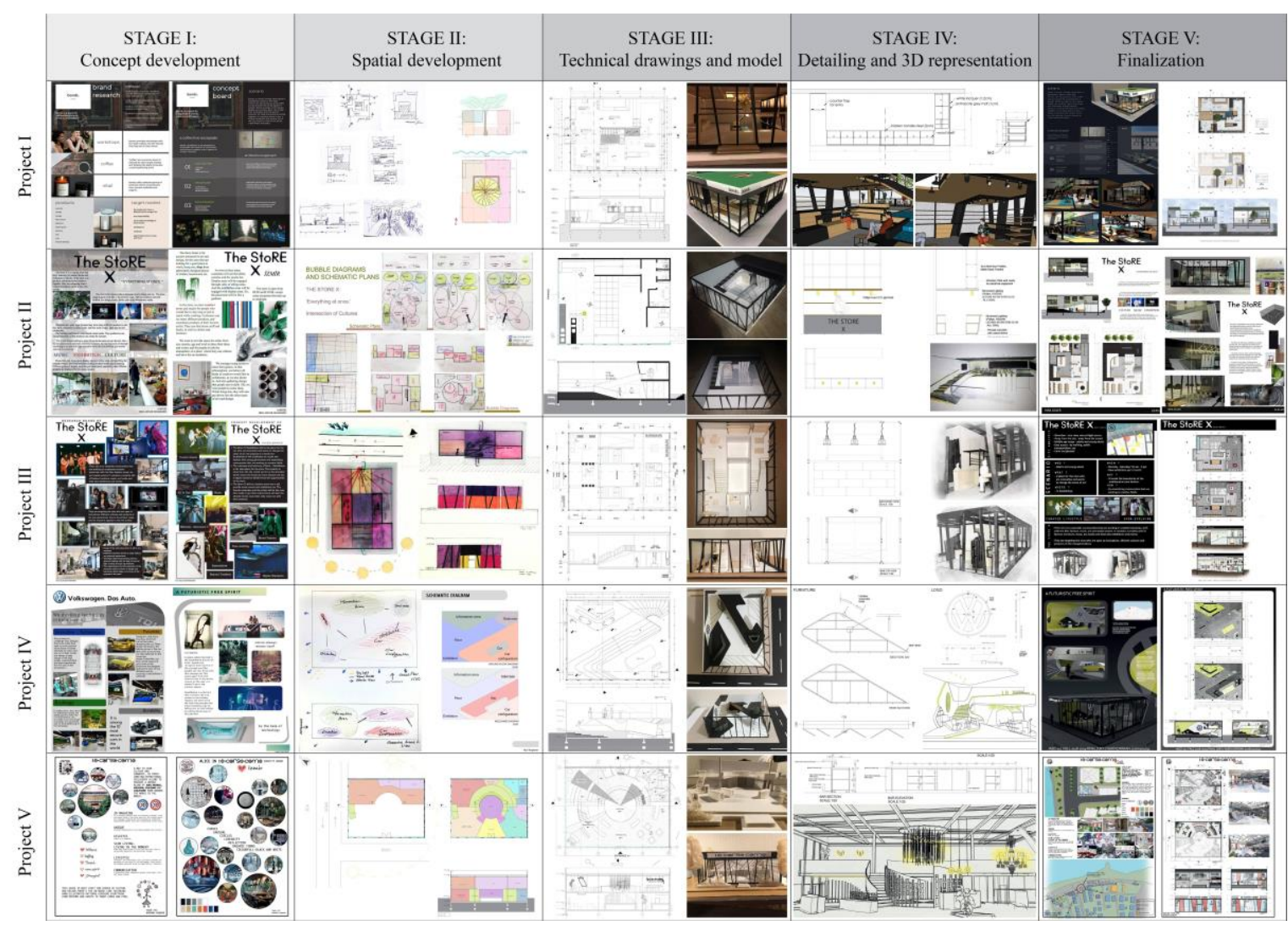

Figure 27 - Design Process and Stages

\section{CONCLUSION}

The study analyzed a selection of project that were carried out during one semester of second-year design studio. It was shown that the proposed method has encouraged the formation of conceptual ideas in response of a defined design problem. Those ideas were led into interior architecture composition during the stages of the design process. By the end of the semester, the students were able to recognize their progress along the whole semester and to benefit from the interdisciplinary approach adopted for the project. This has resulted with various design approaches and creative solutions that were articulated by many aspects of design. It was pointed out that research and practice are in symbiotic relationship and, therefore, they must coexist and buttress each other in a design proposal. Sketch drawings, technical drawings, three-dimensional representations, and models serve different purposes along the design process. However, they are necessary to develop ideas and to communicate with the audience.

This research analyzed the design process structured into five stages along one semester length. Possible future studies may investigate the adopted method on a longer or shorter period of time. In addition, further studies may investigate other fields of research in which interior de-sign has a relevant role. Limitations might involve the low number of projects involved in this study. However, the aim was to analyze projects in depth, rather than investigating several without a detailed understanding. This number can nevertheless be increased and compared in different projects in the future. 
The method adopted in this study can be utilized in interior architecture education for providing the students of a structured design process as well as in professional life. Interior architecture education can benefit from including knowledge regarding the profession's effects on brands, and on the other hand, the interior architecture field contributes greatly to the experience and value of brands.

There is still much more to investigate in the education of interior architecture, especially with new materials and techniques being developed and expectations from interiors changing every day. The ongoing COVID-19 pandemic has significantly affected how interiors are defined and utilized in the short and long term, thus also impacting change in interior architecture education. It is clear that educators of interior architecture see this as a continuous process, always recognizing the changing needs of the field, aiming to create human-focused, well-defined interiors that are created as a result of design thinking and clear design processes. 


\section{Acknowledgements}

The authors would like to thank the members of the studio instructor team, Lect. Haluk Tatari, Lect. Orlin Pontremoli, and course assistant İdil Bakır Küçükkaya who were instrumental in the creation of the design process as well as the projects. The authors would like to express gratitude to Lect. Jörn Fröhlich and Prof. Elvan Özkavruk Adanir for their valuable contribution during the semester. Moreover, authors would like to thank the project owners, Prrıl Alp, Nurdan Coşkun, İkra Güler, Nuri Koparan, and İ. Berk Öndül for their efforts. Last but not least, the authors would also like to thank Çiçek İnşaat Ltd. Şti., and specifically, Mustafa Çiçek for his kind support throughout the project.

\section{Conflict of Interest Statement}

There is no conflict of interest for conducting the research and/or for the preparation of the article.

\section{Financial Statement}

No financial support was received for conducting the research and preparation of the article.

\section{Ethical Statement}

We the authors confirm that the article 'Designing a concept store: an interdisciplinary design process' was written with full consideration to ethical norms and all consents were received from the participants.

\section{Author Contribution Statement}

\begin{tabular}{|l|l|l|}
\hline A. Fikir / Idea, Concept & $\begin{array}{l}\text { B. Çalışma Tasarısı, Yöntemi / Study } \\
\text { Design, Methodology }\end{array}$ & $\begin{array}{l}\text { C. Literatür Taraması / } \\
\text { Literature Review }\end{array}$ \\
\hline D. Danı̧manlık / Supervision & $\begin{array}{l}\text { E. Malzeme, Kaynak Sağlama / Material, } \\
\text { Resource Supply }\end{array}$ & $\begin{array}{l}\text { F. Veri Toplama, Işsleme / } \\
\text { Data Collection, Processing }\end{array}$ \\
\hline $\begin{array}{l}\text { G. Analiz, Yorum / Analyses, } \\
\text { Interpretation }\end{array}$ & H. Metin Yazma / Writing Text & $\begin{array}{l}\text { I. Eleştirel İnceleme / Critical } \\
\text { Review }\end{array}$ \\
\hline
\end{tabular}

All authors have contributed equally to the preparation of this article.

AUTHOR 1: A/B/C/D/E/F/G/H/I

AUTHOR 2: $\mathrm{A} / \mathrm{B} / \mathrm{C} / \mathrm{D} / \mathrm{E} / \mathrm{F} / \mathrm{G} / \mathrm{H} / \mathrm{I}$

AUTHOR 3: $\mathrm{A} / \mathrm{B} / \mathrm{C} / \mathrm{D} / \mathrm{E} / \mathrm{F} / \mathrm{G} / \mathrm{H} / \mathrm{I}$

AUTHOR 4: A/B/C/D/E/F/G/H/I 


\section{REFERENCES}

Ann, M., (2006). Are you experiential. Multi Channel Merchant, 12(8), 10-55.

Babin, B.J. \& Attaway, J.S. (2000). Atmospheric affect as a tool for creating value and gaining share of the customer. Journal of Business Research, 49(2), 91-99.

Baloglu, S. \& Brinberg, D. (1997). Affective images of tourism destinations. Journal of Travel Research, 35(4), 11-15. doi:10.1177/004728759703500402

Bardsley, C. (2017, May 17). What is a successful concept store? Unibox. Retrieved from https://www.unibox.co.uk/news-inspiration/what-makes-successful-concept-store

Beverland, M. \& Morrison, M. (2003). Experience-brand 'fit': a contingent model. Proceedings of the 2003 Society for Marketing Advances Annual Symposium on Retail Patronage and Strategy, US A, 4164.

Bitner, M. J., Booms, B. H. \& Tetreault, M. S. (1990). The Service Encounter: Diagnosing Favorable and Unfavorable Incidents. Journal of Marketing Research, 54(1), 71-84. doi: $10.1177 / 002224299005400105$

Boradkar, P. (2000). Design as Problem-Solving. In R. Frodeman, J. Thompson Klein \& C. Mitcham (Eds.), The Oxford Handbook of Interdisciplinarity (pp. 273-287). Oxford: Oxford University Press.

Both, T. (2016). A D. School Design Project Guide. Hasso Plattner Institute of Design at Stanford.

Carbone, L. \& Haeckel, S. (1994). Engineering customer experience. Marketing Management, 3(3), 8-19.

Ching, F. (1985). Architectural Graphics. New York, NY: Van Nostrand Reinhold.

Clemons, S. A. (2006). Interior Design Supports Art Education: A Case Study. International Journal of Art and Design Education, 25(3), 275-285.

doi:10.1111/j.1476-8070.2006.00494.x

Cochrane, T., \& Munn, J. (2016). EDR and Design Thinking: Enabling Creative Pedagogies. In Proceedings of EdMedia 2016--World Conference on Educational Media and Technology (pp. 315-324). Vancouver, BC, Canada: Association for the Advancement of Computing in Education (AACE). Retrieved April 3, 2021 from https://www.learntechlib.org/p/172969/

Conran, T. (1996). Conran on Retail Design. London: Conran Octopus.

Darbellay, F., Moody, Z., \& Lubart, T. (Eds.). (2017). Creativity, design thinking and interdisciplinarity. Springer Singapore.

De Ruyter, K. \& Wetzels, M. (2000). Customer equity considerations in service recovery: a crossindustry perspective. International Journal of Service Industry Management, 11(1), 91-108. doi: $10.1108 / 09564230010310303$

Demirkan, H. \& Hasirci, D. (2009). Hidden Dimensions of Creativity Elements in design Process. Creativity Research Journal. 21(2): 294-301. doi: 10.1080/10400410902861711 
Doorley, S., Holcomb, S., Klebahn, P., Segovia, K., \& Utley, J. (2018). Hasso Plattner Institute of Design at Stanford. Design Thinking Bootleg.

Dorst, K. (2011). The Core of Design Thinking and its Application. Design Studies, 32, 521-532.

Dubuisson-Quellier, S. (2007). The shop as market space: The commercial qualities of retail architecture. In D. Vernet \& L. De Wit (Eds.), Boutiques and other retail spaces (pp. 28-45). New York, NY: Routledge.

Frampton, K. (2005). The work of architecture in the age of commodification. Harvard Design Magazine, 23, 1-5.

Goodrich, L. W. (2019). Sumak kawsay: Social empowerment through participatory user-centred design in Ecuador. International Journal of Art and Design Education, 38(1), 195-206. doi: $10.1111 /$ jade. 12175

Greenstreet, R. \& Shields, J. W. (1988). Architectural Representation. Englewood Cliffs: Prentice Hall.

Grewal, D., Levy, M., \& Kumar, V. (2009). Customer experience management in retailing: an organizing framework. Journal of retailing, 85(1), 1-14. doi:10.1016/j.jretai.2009.01.001

Hansen, D. E. \& Danaher, P. J. (1999). Inconsistent Performance During the Service Encounter: What's a Good Start Worth?. Jorunal of Service Research, 1(3), 227-235. doi: $10.1177 / 109467059913004$

Hasirci, D. \& Demirkan, H. (2007). Understanding the Effects of Cognition in Creative Decision-Making: A Creativity Model for Enhancing the Design Studio Process. Ceativity Research Journal, 19(2-3), 259-271. doi:10.1080/10400410701397362

Herbert, D. M. (1988). Study drawings in architectural design: Their properties as a graphic medium. Journal of Architectural Education, 41(2), 26-38. doi:10.1080/10464883.1988.10758473

Holbrook, M. B. (1999). Consumer value. A Framework for Analysis and Research. London: Routledge.

Hultén, B. (2011). Sensory marketing: the multi-sensory brand-experience concept. European Business Review, 23(3), 256-273. doi:10.1108/09555341111130245

Keller, K. L. \& Lehmann, D.R. (2006). Brands and branding: research findings and future priorities. Marketing Science, 25(6), 740-59. doi:10.1287/mksc.1050.0153

Kelly, K. E. (2002). Architecture for sale(s). Harvard Design Magazine, 17, 1-6.

Kent, T. (2007). Creative space: design and the retail environment. International Journal of Retail \& Distribution Management, 35(9), 734-745. doi:10.1108/09590550710773273

Klassen, F. (2003). Tangible to intangible. International Journal of Art and Design Education, 22(1), 9299. doi: $\underline{10.1111 / 1468-5949.00342}$

Kotler, P. (1973). Atmospherics as a Marketing Tool. Journal of Retailing, 49(4), 48-64.

Kotler, P. (2000). Marketing Management - The Millennium Edition. New York: Prentice Hall.

Kumar S. (2019). Concept Stores: Bringing Innovative Ideas, Experiences to Indian Malls. Shopping Center News, 12(6), 22-27. 
Levy, S. J. \& Kotler, P. (1979). Toward a Broader Concept of Marketing's Role in Social Order. Journal of the Academy of Marketing Science, 7(3), 232-238. doi:10.1177/009207037900700207

Loe, D. (2002). Psychology of lighting, Light, 10, 10-14.

Mendoza, H. R., Benasconi, C., \& MacDonald, N. M. (2007). Creating New Identities in Design Education. International Journal of Art and Design Education, 26(3), 308-313. doi:10.1111/j.1476$\underline{\text { 8070.2007.00541.x }}$

Micheli, P., Wilner, S. J., Bhatti, S., Mura, M., \& Beverland, M. B. (2018). Doing Design Thinking: Conceptual Review, Synthesis and Research Agenda. Journal of Product Innovation Management (14) Design Thinking in Education: Perspectives, Opportunities and Challenges.

Miller, W. E. (1982). Basic Drafting for Interior Designers. New York, NY: Van Nostrand Reinhold.

Morganosky, M. A., \& Cude, B. J. (2000). Large format retailing in the US: a consumer experience perspective. Journal of Retailing and Consumer Services, 7(4), 215-222. doi:10.1016/S0969-6989(00)00016-3

Münster, A. H. M. B., \& Haug, A. (2015). Design variables and constraints in fashion store design processes. International Journal of Retail and Distribution Management, 43(9), 831-848. doi:10.1108/IJRDM-11-2013-0207

Nistorescu, T., \& Barbu, C. M. (2008). Retail store design and environment as branding support in the services marketing. Management \& Marketing, 6(1), 11-17.

Ostrowski, P. L., O’Brien, T. V. \& Gordon, G. L. (1993). Service quality and customer loyalty in the commercial airline industry. Journal of Travel Research, 32(2), 16-24. doi: $10.1177 / 004728759303200203$

Otnes, C. C., Ilhan, B. E., \& Kulkarni, A. (2012). The language of marketplace rituals: implications for customer experience management. Journal of Retailing, 88(3), 367-383. doi:10.1016/j.jretai.2012.02.002

Padgett, D. \& Allen, D. (1997). Communicating experiences: a narrative approach to creating service brand image. Journal of Advertising, 26(4), 49-62. doi: $\underline{10.1080 / 00913367.1997 .10673535}$

Panke, S. (2019). Design Thinking in Education: Perspectives, Opportunities and Challenges. Open Education Studies, 1(1), 281-306.

Pavel, C. (2016). Concept Stores: A Strategic Approach for creating a Destination Experience. Calitatea, 17(3), 169-172. Retrieved from https://search.ebscohost.com

Peñaloza, L. (1999). Just doing it: a visual ethnographic study of spectacular consumption at Niketown. Consumption, Markets and Culture, 2(4), 337-465. doi: $10.1080 / 10253866.1998 .9670322$

Popescu, D. I., \& Popa, I. (2012). The Option for the Universe of Consumption and the "Efficient Consumer Response" Philosophy. Journal of Eastern Europe Research in Business \& Economics, 1, 1. doi:10.5171/2012.623809 
Puccinelli, N. M., Goodstein, R. C., Grewal, D., Price, R., Raghubir, P., \& Stewart, D. (2009). Customer experience management in retailing: understanding the buying process. Journal of retailing, 85(1), 15-30. doi:10.1016/j.jretai.2008.11.003

Renard, H. (2014). Cultivating Design Thinking in Students through Material Inquiry. International Journal of Teaching and Learning in Higher Education, 26(3), 414-424. (14)

Ryu, K., Lee, H. R., \& Kim, W. G. (2012). The influence of the quality of the physical environment, food, and service on restaurant image, customer perceived value, customer satisfaction, and behavioral intentions. International Journal of Contemporary Hospitality Management, 24(2), 200-223.doi:10.1108/09596111211206141

Schmitt, B. \& Simonsen, A. (1997). Marketing Aesthetics: The Strategic Management of Brands. New York, NY: The Free Press.

Schmitt, B., (1999). Experiential marketing. Journal of marketing management, 15(1-3), 53-67. doi: $10.1362 / 026725799784870496$

Simon, H. A. (1969). The Sciences of the Artificial. Cambridge: MIT Press.

Smith, B. J. \& Colgate, M. (2007). Customer Value Creation: A Practical Framework. Journal of Marketing Theory and Practice, 15(1), 7-23. doi:10.2753/MTP1069-6679150101

Srivastava, M., \& Kaul, D. (2014). Social interaction, convenience and customer satisfaction: The mediating effect of customer experience. Journal of Retailing and Consumer Services, 21(6), 10281037. doi: $\underline{10.1016 / \text { i.j.jetconser.2014.04.007 }}$

Thamrin, D., Wardani, L. K., Sitindjak, R. H. I., \& Natadjaja, L. (2019). Experiential Learning through Community Co-design in Interior Design Pedagogy. International Journal of Art and Design Education, 28(2), 461-477. doi:10.1111/jade.12208

Turley, L. W. \& Milliman, R. E. (2000). Atmospheric Effects on Shopping Behavior: A Review of the Experimental Evidence. Journal of Business Research, 49(2), 193-211. doi:10.1016/S0148$\underline{2963(99) 00010-7}$

Verhoef, P. C., Lemon, K. N., Parasuraman, A., Roggeveen, A., Tsiros, M., \& Schlesinger, L. A. (2009). Customer experience creation: Determinants, dynamics and management strategies. Journal of retailing, 85(1), 31-41. doi:10.1016/j.jretai.2008.11.001

Veryzer, R. W. (1999). A nonconscious processing explanation of consumer response to product design. Psychology and Marketing, 16(6), 497-522. doi:10.1002/(SICI)15206793(199909)16:6\%3C497::AID-MAR4\%3E3.0.CO;2-Z

Wortzel, L. H. (1987). Retailing strategies for today's mature marketplace. Journal of Business Strategy, 7(4), 45-56. doi:10.1108/eb039175

Zomerdijk, L. G. \& Voss, C. A. (2010). Service Design for Experience-Centric Services. Journal of Service Research, 13(1), 67-82. doi:10.1177/1094670509351960 


\section{BIOGRAPHIES OF THE AUTHORS}

\section{Silvia ROLLA}

Born in Milan-Italy, Silvia Rolla received her bachelor's degree in Architecture in 2013 and her master's degree cum laude in Architecture of Interiors in 2015, both from Polytechnic University of Milan. In 2014, she was Erasmus student with scholarship at Escola Superior de Artes e Design in Matosinhos-Portugal. After the studies, she worked as interior architect in Portugal in residential and commercial projects. In 2017, she moved to Izmir-Turkey where she is currently full-time lecturer at Izmir University of Economics. She teaches design studio, construction and materials, and drawings courses in the Department of Interior Architecture and Environmental Design, Faculty of Fine Arts and Design.

\section{Deniz HASIRCI}

Born in Reading-England, she received her bachelor's, master's, and PhD from the Department of Interior Architecture and Environmental Design at Bilkent University. She worked professionally at Eczacibasi-Intema in Ankara. She was a Fulbright scholar between 2001 and 2002 at North Carolina State University. Her articles have been published in journals as, The Journal of Creative Behavior, Creativity Research Journal, METU Journal, and Journal of Interior Design. She began working at Izmir University of Economics in 2006 and became full professor in 2019. She was department head between 2010-2017. She teaches Design Studio and Environment-Behavior Research. She is one of the two project coordinators of the DATUMM: Documenting and Archiving - Turkish Modern Furniture (datumm.org) project. She is also a member of The Fulbright Alumni, Chamber of Interior Architects of Turkey, and EDRA (Environmental Design Research Association). She is a founding committee executive member of DOCOMOMO $\mathrm{Tr}$ Interior.

\section{Yücel Selin ANAL}

Yucel Selin Anal is an architect and part time instructor in Interior Architecture and Environmental Design, İzmir University of Economics. She was born in Izmir and completed her high school degree in American Collegiate Institute, Izmir. She has pursued her Bachelor's and Master's degrees in Architecture at Wentworth Institute of Technology, Boston, M.A. in 2008 and 2010, respectively. Selin has worked as an architect in both residential and commercial projects with Norm Architects, Istanbul, for two years, and as an architectural designer with SC Design Group in California for a year and a half. Between years 2008 - 2015, Selin has also assisted Professor Weldon Pries from Wentworth Institute of Technology, in Istanbul Studio Project, an urban design and architecture course. Since 2015, she has been lecturing in Izmir University of Economics.

\section{Zeynep EDES}

Zeynep Edes is a lecturer in Interior Architecture and Environmental Design Department, Izmir University of Economics in Turkey. She gave several lectures since 2008, while working professionally in market as an interior designer; in design,application and control phases. Edes had graduated from Bilkent University, Department of Interior Architecture and Environmental 
Design. She was the recipient of the Philips Interuniversity Lighting Design Contest Award in 1999. She studied in lighting design projects and consultancy, presented a study in a conference named Experiencing Light 2012, in Eindhoven Technical University. Between 2008-2016, she was in the administration of the Chamber of Interior Architects of Izmir Branch in Turkey. 